\title{
THE
}

\section{Using Non-Dietary Gastropods in Coastal Shell Middens to Infer Kelp and Seagrass Harvesting and Paleoenvironmental Conditions}

Amira F. Ainis

René Vellanoweth

Queeny G. Lapeña

Carol S. Thornber

University of Rhode Island, thornber@uri.edu

Follow this and additional works at: https://digitalcommons.uri.edu/bio_facpubs

The University of Rhode Island Faculty have made this article openly available.

Please let us know how Open Access to this research benefits you.

This is a pre-publication author manuscript of the final, published article.

Terms of Use

This article is made available under the terms and conditions applicable towards Open Access Policy Articles, as set forth in our Terms of Use.

Citation/Publisher Attribution

Ainis, A. F., Vellanoweth, R., Lapeña , Q. G., \& Thornber, C. S. (2014). Using non-dietary gastropods in coastal shell middens to infer kelp and seagrass harvesting and paleoenvironmental conditions. Journal of Archaeological Science, 49, 343-360. http://dx.doi.org/10.1016/j.jas.2014.05.024 


\title{
Using Non-Dietary Gastropods in Coastal Shell Middens to Infer Kelp and Seagrass Harvesting and Paloenvironmental Conditions.
}

Amira F. Ainis ${ }^{1}$ (Corresponding author), René L. Vellanoweth ${ }^{2}$, Queeny G. Lapeña ${ }^{2}$ and Carol S. Thornber $^{3}$

${ }^{1}$ Department of Anthropology, University of Oregon, 1585 East $13^{\text {th }}$ Ave., Eugene, OR 97403, aainis@uoregon.edu (626)529-6030)

${ }^{2}$ Department of Anthropology, California State University, 5151 State University Dr., Los Angeles, CA 90032, rvellan@ calstatela.edu, qlapena@gmail.com

${ }^{3}$ Department of Biological Sciences, University of Rhode Island, 120 Flagg Rd., Kingston, RI 02881, thornber@uri.edu

\begin{abstract}
Archaeologists analyzing shell middens typically focus on larger $(>2 \mathrm{~cm})$ mollusks to examine subsistence practices, impacts on littoral habitats, and paleoenvironmental conditions as well as a host of other natural and cultural phenomena. Small $(<2 \mathrm{~cm})$, non-dietary gastropods in archaeological shell middens also provide important clues regarding human resource procurement in littoral areas and coastal paleoenvironments. We present data from two sites on the California Channel Islands to demonstrate the range of information that can be gained by analyzing small gastropod shells. Identifications revealed the remains of over 4,500 non-dietary small gastropods from 75 taxa. Human harvesting of marine macrophytes is suggested by the presence of 18 species that are predominantly associated with seaweeds and seagrasses. Quantification measures revealed high diversity and equitability indices, oscillating taxonomic richness, and decreasing densities through time at both sites. Likelihood ratio tests revealed differences in assemblage composition between Early Holocene and later components at one site and demonstrated similarities in the relative composition of non-dietary shell assemblages between both sites during the Middle Holocene. Incorporating detailed studies of less conspicuous "incidental" shellfish remains in archaeological midden studies has the potential to contribute to our understanding of past human land use practices and littoral paleoecology. Our
\end{abstract}


findings are applicable to archaeologists working in coastal settings around the world, as well as marine ecologists interested in intertidal paleo-habitats and kelp forest ecosystems.

Keywords: coastal archaeology, shell midden analysis, kelp associates, seagrass associates, nondietary incidental shells, California Channel Islands. 


\section{Introduction}

Small, non-dietary shells are accidentally incorporated in archaeological middens through a variety of mechanisms (see Claassen 1998; Stiner 1999), and can provide significant information through their associations with purposely harvested perishable resources such as marine algae and plants. Marine benthic macrophytes, including seaweeds (multicellular marine macroalgae) and seagrasses (angiosperms, flowering sea plants), provide the foundation for healthy marine ecosystems and vibrant littoral habitats that have attracted human foragers for over 100,000 years (Avery et al. 2008; Erlandson 2001; Klein et al. 2004; Marean et al. 2007; Ramos et al. 2011) and other members of our genus for even longer (Cortéz-Sánchez et al. 2010; Cunane and Stewart 2010; Erlandson 2010; Stiner 1994; Szabó and Amesbury 2011). Roughly 150 species of seaweed are considered edible (Kumar et al. 2008) and used as food worldwide. These species contain various compositions of macro and micro-nutrients (Aaronson 1986; Chapman and Chapman 1980; Dawcyzynski et al. 2006; Druehl 2000; Fleurence 1999; Floreto and Teshima 1998; Guiry and Blunden 1991; Hong et al. 2007; MacArtain et al. 2007; Nisizawa et al. 1987; Turner 2003), with some species boasting mineral contents higher than many land plants (Indegaard and Minsaas 1991; Ito and Hari 1989; Rupérez 2002), making them a valuable food source. Seaweeds and seagrasses are also used for fuel, roofing and matting when dried (McRoy and Helfferich 1980:298-299; Mouritsen 2013:5-21), to underlay and wrap burials for cremation (Photos-Jones et al. 2007), as raw material for the production of cordage, nets, and baskets (Connolly et al. 1995; Scagel 1961; Turner and Bell 1973; Vellanoweth et al. 2003), and to wrap and steam food (Turner and Bell 1973). Unfortunately, Seaweeds and seagrasses rarely survive in the archaeological record and only preserve under the most favorable conditions, for example caves and rockshelters (e.g., Connolly et al. 1996; Vellanoweth et al. 2003) and some 
open-air sites such as Monte Verde, Chile, where nine species of marine algae were identified from archaeological features and directly dated to roughly 14,000 years ago (Dillehay et al. 2008). Despite the fact that macrophytes are highly perishable, the small gastropods that live on them have been identified in archaeological contexts dated as far back as the Upper (Colonese and Wilkens 2005) and Lower Paleolithic (Barrière 1969), and hypothesized as indirect evidence that people brought seaweed to cave sites.

In the fossil record, the lack of evidence for kelp (large brown seaweeds in the family Laminariaceae that frequently form large underwater forests) requires researchers to use climatic models and historical distributions of kelp and their associates to infer their evolution and radiation across the world (Estes and Steinberg 1988). As related by Estes and Steinberg (1988:21); seaweed associates include kelp and seagrass limpets that possess unique morphologies and form close associations with particular marine algae and plants. Unlike kelps, seagrasses and associated limpets left evidence of their antiquity in fossil records of Eocene age; however, limpets bearing the unique morphological characteristics of associations with large brown algae only appear in the fossil record about 3 million years ago. The relatively sudden appearance of kelp associated limpets at this time has led researchers to suggest that this was when the widespread proliferation of kelps likely occurred (Estes and Steinberg 1988:21-22). We are proposing to use seaweed associates in a similar fashion, to signal, or infer, the harvesting of seaweeds and seagrasses that have not left direct evidence of their use in the archaeological record.

We present shellfish data from a trans-Holocene multi-component rockshelter on San Miguel Island (ca 8,500 - 1,000 cal BP) and a Middle Holocene open-air dune site on San Nicolas Island (ca 4,800 - 3,600 cal BP), located off the southern California coast (Figure 1). We 
identify several species of small gastropods that live predominantly (sometimes exclusively) on marine macrophytes (Figures 2 and 3), and we suggest that the presence of these shells in archaeological deposits serve as indirect evidence for human harvesting of these perishable resources. Varieties of other small gastropods are presented here with possible explanations for their presence in archaeological deposits. The aims of this study are to describe small gastropod assemblages from archaeological shell middens by: 1) quantifying non-dietary shells and placing them in habitat based categories; 2) employing heterogeneity measures and cross tabulation frequency distributions to investigate the significance of patterning; 3) examining inferred human harvesting of marine macrophytes through the presence of seaweed and seagrass associates; 4) presenting ethnographic accounts from coastal areas north and south of the Channel Islands as well as on the mainland coast as examples of marine macrophyte use by Native people in the greater region; and 5) exploring possible paleoecological and paleoenvironmental implications signaled by the presence of non-dietary shells, though this discussion remains exploratory.

\section{Background}

\subsection{Ethnohistoric Accounts of Seaweed and Seagrass Use from Western North America}

Substantial and varied uses of seaweeds and seagrasses by Native People have been extensively documented for the Pacific Northwest Coast of North American and the Gulf of California. Multiple species of marine macroalgae and angiosperms were harvested, utilized and traded, forming a pivotal role in the lifeways of coastal peoples. Ethnographic accounts have documented a rich linguistic heritage associated with kelps and seagrasses including primary names differentiating stages of growth and aspects of use, suggesting considerable antiquity (Berlin 1973; Felger et al. 1980; Turner 1995, 2003). 
Several marine macroalgae, including sea wrack (Fucus gardneri, Fucus sp.), giant kelp (Macrocystis pyrifera), bull kelp (Nereocystis leutkeana), and red lavers (Porphyra spp.) were (and in some cases still are) utilized by Native Peoples of the Pacific Northwest Coast (Ager and Ager 1980; Turner 1995, 2003; Turner and Bell 1973). Several species of brown algal blades (Egregia menziesii, Fucus sp., M. pyrifera, and N. leutkeana) were used to catch herring eggs during spawning season. Herring spawn covered blades were dried then bundled and stored for winter use, or traded as a valuable item through extensive coastal and inland networks (Ager and Ager 1980; Turner 1995; Turner and Bell 1973; Turner and Loewen 1998). Kelp blades were also used as heated poultices and the long hollow tubular stipes were used to store oil and grease and to make ropes, fishing nets and lines, and harpoon lines (Turner and Bell 1973).

To a lesser degree, marine seagrasses were also used for food. Surfgrass (Phyllospadix scouleri and $P$. torreyi) and eelgrass (Zostera marina) plants were dried and formed into cakes for winter consumption, and eelgrass roots and rhizomes were used to flavor meat (Turner 1995:53-54). The Kwakwaka'wakw participated in an Eelgrass Feast, in which uncooked rhizomes, stems, and bases were eaten as the food of their mythical ancestors (Turner 1995:54), suggesting antiquity to the practice of consuming eelgrass. In addition, eelgrass and surfgrass were utilized by coastal tribes along western North America, including the Channel Islands, as basket weaving materials (Scagel 1961).

The Seri (Koykáak) Indians of the Sonoran Desert, Mexico, are the only people known to have extensively harvested the seeds of a submerged marine angiosperm (Felger and Moser 1973, 1976, 1985; Felger et al. 1980). Not only were eelgrass seeds utilized, they were one of the most important traditional foods of the Seri (Sheridan and Felger 1977). Eelgrass flour was of particular importance as a storable food; it was placed in sealed pottery vessels and hidden in 
caves with other edible items for times of need (Felger and Moser 1970, 1971, 1976). In addition to its dietary value, eelgrass was also used to line baskets and sea turtle carapaces for the placement of meat and other foods, spread over the frame of shelters for shade and roofing, and in the construction of children's toys (Felger et al. 1980). In addition, eelgrass has been used to determine seasonality of an archaeological event. In one instance where eelgrass was found covering a group of burials, the lack of fruit, seeds or flowering structures suggested it was collected before its reproductive structures emerged, implying the burial event occurred in winter (Felger et al. 1980:272).

\subsection{California Channel Islands: Kelp Forests and Nearshore Environments}

The California Channel Islands consist of eight islands located off the coast of southern California. They are divided into two geographical groupings, the northern Channel Islands, consisting of Anacapa, Santa Cruz, Santa Rosa, and San Miguel Islands, and the southern Channel Islands of Santa Catalina, Santa Barbara, San Clemente, and San Nicolas. Although the Channel Islands are located in relative proximity, a mixture of geographic, oceanographic, physical, and biological features produce unique nearshore communities on each island, dictating local marine productivity and contributing to the diversity and abundance of marine resources along their shores (Engle 1994; Schoenherr et al. 1999). The outer islands, San Miguel and San Nicolas, reap the benefits of the colder nutrient rich waters of the California Current that extends down the coast from northern California. Traveling northward and moving up from Baja California, the California Countercurrent (or Davidson Current) brings warmer waters that bathe Santa Catalina and San Clemente before moving out to the other islands. Fluctuations in water temperature associated with these currents produces varying sizes of offshore kelp beds, and 
different invertebrate compositions in intertidal environments on a single island, as well as among islands.

Californian kelp forests are composed primarily of large brown algae; the dominant subtidal species include the giant kelp Macrocystis pyrifera and the bull kelp Nereocystis luetkeana (Abbott and Hollenberg 1976; Mondragon and Mondragon 2003). Based on substantial differences in oceanic conditions among marine habitats along the coast of California, kelp forests surrounding the California Channel Islands have been placed within the "Southern California" biogeographic range extending from Point Conception, California to Punta Banda, Baja California, Mexico (Edwards 2004). These kelp forests are dominated by the canopyforming giant kelp (Macrocystis pyrifera), along with stipitate subcanopy kelps (Eisenia and Pterygophora) and nonstipitate low-lying kelps (Dictyoneuropsis and Laminaria), with varying amounts of other kelps such as the surface canopy feather-boa kelp (Egregia menziesii) (Dayton 1985; Graham 2004; Graham et al. 2003; Mann 1973; North 1971; Rosenthal et al. 1974). Giant kelp forests sustain extremely varied and dynamic ecological communities, creating an extensive ecological web of interdependent species that benefit from the reduction in current intensity found in their immediate surroundings (Coyer 1986; Dayton 1985; Dayton et al. 1998; Foster and Schiel 1985; Graham 2004; Graham et al. 2003; Jones 1971; North 1971). Coastlines of the Channel Islands also harbor large surfgrass (Phyllospadix spp.) and eelgrass (Zostera spp.) meadows, anchored in shallow subtidal to sublittoral zones of rocky intertidal areas and exposed during low tides (Mondragon and Mondragon 2003).

Primary intertidal environments on San Miguel and San Nicolas islands include protected outer coast habitats, semi-sheltered coastlines often with offshore kelp beds, and open coast habitats, characterized as unprotected surf pounded shores. Within varying habitat types a range 
of physical and biological factors influence the proliferation of associated biota (Brandon and Rokop 1985; Hinton 1987; Lewis 1964; Little et al. 2009; Ricketts et al. 1985; Stephenson and Stephenson 1972). The plethora of shell midden sites on the Channel Islands suggests that rocky intertidal communities were utilized extensively by humans. Rocky shores form relatively stable substrate, promoting high diversity and stable communities of the larger shellfish collected for consumption.

The archaeological sites discussed in this paper are located on the coast, overlooking rocky intertidal habitats with associated kelp beds (Figure 4). Midden constituents consist predominantly of black abalone (Haliotis cracherodii), California mussel (Mytilus californianus), and black turban snail (Chlorostoma funebralis), all of which are found in the upper to middle intertidal zone. Other common shellfish species include red abalone $(H$. rufescens) and wavy top shell (Megastraea undosa), found in the lower to subtidal zone, and sea urchin (Strongylocentrotus spp.), found in middle intertidal to subtidal zones, demonstrating that people collected from the full range of intertidal zones/habitats. Additional dietary species include brown turban snails (C. brunnea), several species of crab and chiton, and numerous limpet species.

\subsection{Channel Islands Archaeology}

The Channel Islands have a long and continuous record of human occupation, with the northern islands containing archaeological sites dated to almost 13,000 years ago and representing some of the oldest evidence for coastal lifeways on the west coast of North America (Erlandson et al. 2011b; Johnson et al. 2002; Rick and Erlandson 2012). Numerous studies investigating trans-Holocene human-environmental dynamics on the Channel Islands demonstrate that people relied on a relatively consistent suite of key resources through time 
(Braje et al. 2012; Erlandson et al. 2005; Rick 2011), showing small-scale variable impacts on intertidal habitats (Braje et al. 2007; Erlandson et al. 2008, 2011a; Rick et al. 2005a, 2008). General subsistence trends for the region suggest that shellfish provided a dietary staple during the Early and Middle Holocene, with the use of near and offshore fisheries increasing through time, replacing shellfish as a dietary staple during the Late Holocene (Braje et al. 2012; Erlandson et al. 2009; Glassow 1993; Kennett 2005; Rick et al. 2005a). The importance of marine mammal and cetacean hunting varied through time depending on location and the productivity of island and offshore rookeries (Braje et al. 2011; Colten and Arnold 1998).

\section{Archaeological Sites and Methodology}

\subsection{Cave of the Chimneys (CA-SMI-603)}

Cave of the Chimneys, located on the northeast coast of San Miguel Island, is a multicomponent site containing approximately 7,500 years of human occupation. The rockshelter currently sits on a steep cliff face roughly 12 meters above a rocky coastline and is accessible by a narrow ledge on the southeast side of the shelter (Figure 5). The cave consists of andesitic conglomerate in a sandy matrix and appears to have been formed by marine erosion during high interglacial sea levels of the Pleistocene. The rockshelter measures approximately 10 meters deep by 12 meters wide with a skylight measuring roughly 1.5 meters in diameter. The large east facing entrance provides adequate lighting and protection from the strong northwesterly winds that pummel San Miguel Island most of the year (Johnson 1973:63). Sediments fill the site to less than one meter toward the back of the rockshelter and gently slope downward forming an apron at its mouth. Deposits are intact, finely stratified, and extremely well-preserved.

Archaeological excavations revealed seven distinct, chronologically intact stratigraphic layers representing intermittent occupational phases that were radiocarbon dated to between 
about 8,600 and 1,000 cal BP (Table 1). A total of 1,588 liters was excavated between 1997 and 1999. The exceptional preservation at this site is evidenced by delicate strands of seagrass cordage found in the basal components and dated to the Early Holocene (Vellanoweth et al. 2003). Faunal constituents, including over $122 \mathrm{~kg}$ of shell and over $2 \mathrm{~kg}$ of bone (predominantly fish), demonstrate the importance of rocky intertidal and nearshore habitats to site inhabitants (Ainis 2012; Ainis et al. 2011; Ainis and Vellanoweth 2012; Rick et al. 2005b; Vellanoweth et al. 2002).

\subsection{CA-SNI-40}

Situated on the northwest coast of San Nicolas Island, CA-SNI-40 is a large linear sand dune with paleosols and occupational middens, measuring approximately $1 \mathrm{~km}$ long (Figure 6). The surface of the site resembles a red abalone midden, though erosional exposures and controlled excavations revealed several discrete deposits within two main components dated to between 4200 and 3800 cal BP (Table 2). A Middle Holocene cemetery located on the east end of the dune was excavated in the late 1950s and dated to the same time period as the midden (Reinman and Townsend 1960). Many artifacts from the cemetery correspond directly with items uncovered in the midden, suggesting continuity between the cemetery and associated midden at this site. Recent excavations took place between 2010 and 2011. Five loci were sampled and 301 x 1 meter units were excavated, removing 8,185 liters of archaeological materials and soil matrix. The samples discussed here are from two 1 x 1 meter units (11 and 12A) in Locus E, located on the top of the dune. The components are primarily comprised of red (H. rufescens) and black abalone (H. cracherodii), wavy top shells (Lithopoma undosa), and other rocky intertidal shellfish and crustacean taxa along with the bones of teleost fishes, elasmobranches, sea mammals and marine birds. A wide variety of artifacts in various stages of production, 
including several types of Olivella (Callianax biplicata)beads, abalone nacre sequins, bone tools, and pendants made from imported soapstone was uncovered during excavations. The relatively large size of the midden deposit at this site and the short temporal chronology of radiocarbon dates suggests CA-SNI-40 was utilized extensively for a brief period of time.

\subsection{Analytical Methods}

The small gastropods analyzed in this study were excavated from sites CA-SMI-603 and CA-SNI-40 using standard stratigraphic methods of recovery and recordation. The minimum number of individuals (MNI) was calculated for each taxonomic designation using apices (though most shells were whole due to their small size), and all shell remains were weighed using a digital scale to two decimal places. All identifications were made to the lowest taxonomic level possible using comparative collections at the Los Angeles County Natural History Museum, California State University, Los Angeles, and the University of Oregon, as well as multiple reference books (Allen 1969; Brandon and Rokop 1985; Carlton 2007; Hinton 1987; McLean 1978; Morris 1966; Morris et al. 1980; Rehder 1981).

Density measures were calculated by dividing the minimum number of individuals (MNI) for each taxonomic group over the excavated volume $\left(\mathrm{m}^{3}\right)$ for each stratum and feature. Because identifications of small gastropods were not always possible at the species level, we calculated taxonomic richness of each stratum by counting the total number of taxonomic categories identified therein. An analysis of covariance (ANCOVA) was used to investigate changes in taxonomic richness through time. Along with shifts in foundation species, changes in taxon richness have the potential to illuminate shifts in community composition of intertidal gastropods (e.g., Needles and Wendt 2013). Diversity and equitability measures, utilizing richness and abundance data from each taxonomic category, were used to describe the heterogeneity of 
analyzed samples. The Shannon-Weaver function (Reitz and Wing 2008) was used to calculate taxonomic diversity (H') measured as:

$$
H^{\prime}=-\Sigma\left(p_{i}\right)\left(\log _{e} p_{i}\right)
$$

where $H^{\prime}$ is the heterogeneity measurement of the sample; $p_{i}$ is the relative abundance of each species or genus within the sample (calculated using MNI of all identified small gastropods); and $\log _{e} p_{i}$ is the logarithm of $p_{i}$. Equitability (V': equivalent to Pielou's evenness index J') was measured as:

$$
V^{\prime}=H^{\prime} / \log _{\mathrm{e}} S
$$

where $H^{\prime}$ is the Shannon-Weaver function and $S$ is the total number of taxa (using lowest possible taxonomic identifications) in each stratum or feature. Analyses of variance (ANOVA) were computed to determine if significant differences in species density among strata at each site were present. The use of density values rather than MNI allowed us to factor out sample size as a contributing variable. Non-parametric contingency tests (G-Test of Independence) were used to distinguish similarities or differences in community composition of seaweed associates, gravel dwellers, mollusk associates, and rock and boulder dwellers; and investigate changes in the relative proportions of shellfish from our four categories (Type 1-4, see Table 3) both within and between archaeological sites. ANCOVA and ANOVA tests were run in SAS 9.2 and G-Tests were run in BiomSTAT (Sokal and Rohlf 2012). All G-values are reported with Williams correction, degrees of freedom (df), and $p$ values expressed as $<0.05$ with $\alpha=0.05$ unless otherwise noted.

\section{Results}

Excavations of Unit 1 at CA-SMI-603 yielded a total of $122 \mathrm{~kg}$ of shell identified to 78 species, 16 genera, and seven higher taxonomic levels (Ainis 2012). A total of $42 \mathrm{~kg}$ of shellfish 
remains was recovered from Units 11 and 12A at CA-SNI-40 and identified to 42 species, 11 genera, and three higher taxonomic levels. A total of 4,568 individuals belonging to 34 genera and 61 species of small gastropods was identified in this study, excluding larger shellfish taxa known to be of dietary value. We grouped the small, non-dietary gastropod shells into four categories (Type 1-4) based on substrate, habitat, and associations with other shellfish. Our categories are defined in Table 3 and general ecological information for each species is presented in Table 4.

\subsection{Application and Interpretation}

\subsubsection{Intrasite Analysis: CA-SMI-603}

Analysis of small gastropods from Cave of the Chimneys resulted in the identification of 3,305 individuals belonging to 28 genera and 49 species (Table 5), with seaweed and seagrass associates comprising close to $26 \%$ of the MNI of small gastropods. The assemblage is dominated by small limpets and slipper snails (Figure 7). Diversity and equitability indices reveal a high diversity of taxa accompanied by relatively high equitability throughout the deposit (Figure 8), indicating a fairly even distribution of a large variety of taxa. An analysis of covariance demonstrated that there is no linear relationship between taxonomic richness and time (strata) at this site (ANCOVA; $\left.\mathrm{F}_{1,4}=0.13, p=0.7375\right)$. While richness oscillates through time (Table 6), densities follow a downward trend (Figure 9), indicating that although most taxa continue to be present through time their numbers decline. Sample size can be ruled out as a factor affecting the decline in density (from 3,367 MNI/m ${ }^{3}$ in Stratum VII to $1,285 \mathrm{MNI} / \mathrm{m}^{3}$ in Stratum II), as Strata II and IV contain the largest excavated volumes (see Table 6 and Figure 9 for density values and excavated volumes). Furthermore, we found that differences in species densities among strata are highly significant and not related to sample size $\left(\right.$ ANOVA; $F_{65,300}=$ 
$6.72, p<0.0001)$. Overall, we found significant differences between strata and relative abundances of shells in the four categories were significant $(\mathrm{G}=155.868, \mathrm{df}=15, p=0)$. However, these data contained non-significant subsets that show similarities among some strata and the four shell types. These subsets include: Strata VI and VII $(G=23.5391)$ and Strata II, III, and VI $(G=22.6048)$, suggesting that primary differences in frequency patterning occur between basal deposits and upper components.

Interestingly, these data coincide with reconstructions of post-glacial shifts in giant kelp forests off the coast of mainland California, which predict increased kelp forest biomass during the Terminal Pleistocene and Early Holocene before declining rapidly as sea surface temperatures rose in the Middle Holocene (Graham et al. 2010). Kelp forests surrounding the Channel Islands were proposed to have reached peak productivity during the Early Holocene followed by a significant decrease (50-80\%) in kelp forest productivity and associated resources by the later part of the Middle Holocene as climatic conditions warmed (Graham et al. 2010:404). Though tentative, it is possible that data patterning for small gastropod assemblages at CA-SMI-603 reflect a decline in local kelp biomass between the time when Strata V and IV were deposited, coinciding with declining kelp productivity as proposed by Graham and colleagues (2010). On the other hand, changes in human settlement and land use patterns are equally valid cultural variables that could explain the distribution of small gastropods at this site.

\subsubsection{Intrasite Analysis: CA-SNI-40}

Analysis of small gastropods from two units at CA-SNI-40 revealed 1,263 identifiable individuals classified to 24 genera and 38 species (Table 7), with seaweed and seagrass associates making up roughly $22 \%$ of small gastropods. This assemblage is dominated by small limpets (Figure 10). Diversity and equitability measures show relatively high diversity, with 
slight drops in transitional strata (Stratum IIB) and discrete features, and consistently high equitability among taxa (Figure 11). We found no linear relationship between taxonomic richness and time (strata) at this site (ANCOVA; $\left.\mathrm{F}_{1,2}=0.40, p=0.5929\right)$. Although richness is relatively consistent in the two main strata (IIHC and IIHR), it drops in the transitional layer (IIB) and in the distinct component designated as "dark feature" (Table 6). Density measures are highest in the "dark feature" and decrease slightly through time (Figure 12). Percentages of MNI for kelp and seagrass associates confirm density measures, following a similar pattern of lower percentages through time with a spike in the "dark feature" (Table 6). Differences in species densities among strata are significant (ANOVA; $\left.\mathrm{F}_{44,123}=9.73, p=<0.0001\right)$. Overall, differences between strata relative abundances of shells in the four categories are significant $(G=$ 28.3468, $\mathrm{df}=9, p=0.0008)$. However, these data contained non-significant subsets that show similarities among some strata and the four shell types, including Strata IIHR and IIHC ( $\mathrm{G}=$ 14.6331). This suggests that primary differences occur in the transitional layer and discrete feature.

The small gastropod assemblage from the "dark feature" reveals a drop in taxonomic richness along with an increase in density of seagrass and seaweed associates, which is $239 \%$ higher in this feature than in the surrounding midden (IIHC). The seaweed limpet (Lottia insessa) reaches its highest density in this component, where it makes up almost $22 \%$ of small gastropods, with combined seaweed and seagrass associates composing over $36 \%$ of small gastropod MNI, the highest in any deposit discussed here. This high concentration of seaweed associates marks the presence of a distinct activity area where kelp was likely processed in some way and potentially eaten. It is possible that this feature is the partial remains of a "shell bake," 
in which edible shellfish were wrapped in seaweed and steamed, a hypothesis supported by the unusually high density of seaweed associates.

\subsection{Intersite Comparison}

Data from CA-SMI-603 and CA-SNI-40 are presented and compared to provide examples of inferred seaweed and seagrass harvesting through the identification and analysis of non-dietary shells, and to explore tentative interpretations signaled by the presence of ancillary shells. Our combined analysis of the shells recovered from two distinct site types on the California Channel Islands identified a total of 4,568 small gastropods belonging to 75 taxa. Diversity and equitability measures fall within very similar ranges and persist through time at both sites despite distinct differences in site type, location, and chronology. Consistently high diversity and evenness measures suggest that a wide variety of small gastropods was included in these deposits without dominance of any single taxon. Taxonomic richness fluctuates through time at both sites and is lower at CA-SNI-40 than at CA-SMI-603, possibly reflecting the distance of each site from the coast and/or differential preservation due to the relative protection afforded deposits in rockshelters vs. those left exposed to the elements at open-air dune sites. Alternatively, taxonomic richness could reflect small scale differences in the distribution and abundance of shellfish communities during particular times in the past, configurations controlled by the intensity of shellfish harvesting by humans and other predators, as well as by a variety of environmental factors.

Although richness measures are variable between sites, overall density measures are surprisingly similar (Table 6) as are relative percentages of shells belonging to each of the four categories (Table 3). Although decreasing trends in density are evident at both sites, the trend is more pronounced at CA-SMI-603, which contains a much longer occupational history. 
Decreasing trends in density could be reflective of a number of factors pertaining to human decision making and/or the environment, including variables such as changes in human harvesting practices and foraging locations, shifts in site function and settlement, regional or local environmental fluctuations, or decreasing kelp forest biomass as proposed by Graham et al. (2010), which in turn affects species recruitment, settlement, and productivity. Our primary goal for this paper, however, is to highlight the use of marine macrophytes as inferred by epifauna in archaeological contexts and to provide interpretive possibilities for future studies.

Comparing total MNI values for small gastropods at each site reveal differences in community composition (Type 1-4) between sites $(\mathrm{G}=20.8549, \mathrm{df}=3, \mathrm{p}=.0001)$. Differences in the composition of small gastropod assemblages for Early (CA-SMI-603, Strata VI and VII), Middle (CA-SMI-603, Strata III-V; CA-SNI-40, all components), and Late (CA-SMI-603, Stratum II) Holocene time periods reveal significant differences among temporal periods $(\mathrm{G}=$ 78.6775, $\mathrm{df}=9, \mathrm{p}<.0$ ), with Middle and Late Holocene components forming a non-significant subset $(\mathrm{G}=5.9531)$. This similarity in relative frequencies between Middle and early Late Holocene components at CA-SMI-603 and CA-SNI-40 indicate that similar proportions of shells from each type were collected during roughly the same time period on two different islands, and that the Early Holocene components vary significantly from later components.

While there are changes in relative percentages and sizes of key shellfish taxa in these deposits, the primary suite of dietary shellfish is fairly consistent, suggesting a slight depression in intertidal productivity due to extensive harvesting during a relatively short time span. If this decrease in density reflects decreasing populations through time, it could be reflective of diminished offshore kelp beds exposing rocky intertidal taxa to increased wave action and disturbance, limiting settlement and survival. The overall trend of consistently high taxonomic 
diversity at both sites through time testifies to the relative high stability of rocky shore communities, which rapidly recover from exploitation in most instances (see Dye et al. 1994; Hockey and Bosman 1986; Moreno et al. 1986), and likely speaks to the knowledge of islanders who understood how to intensively harvest intertidal shellfish without causing primary species extinctions or severe ecosystem disruption.

\subsection{Behavioral Implications}

Although non-dietary shells are likely riders/hitchhikers and thus incidental inclusions to archaeological middens, the question we wish to explore is, how were they included and what does their presence in an archaeological shell mound indicate? As some of these small species live directly on other larger shellfish their presence indicates the harvesting and use of their host species, while other small gastropods can be used to infer the harvesting of the marine vegetation they live on and consume.

\subsubsection{Shellfish Harvesting Inferences}

Small rider species, such as $G$. norrisiarum, can be useful in instances where the host shell may no longer be present because it was utilized in tool production or for ornamental purposes. This small slipper shell is known to live predominantly on Norrisia norrisi, as implied by its name. While excavated materials from CA-SMI-603 revealed only one identifiable fragment of $N$. norrisi, the presence of $G$. norrisiarum in several strata suggests that perhaps $N$. norrisi was collected and brought to the site but was not incorporated into the midden because the shell was utilized in the manufacturing of ornaments and fishhooks. Interestingly, these two species of shellfish appear together in both units sampled from CA-SNI-40; strata containing $N$. norrisia also contain G. norrisiarum, but neither is present in deposits without the other.

\subsubsection{Indirect Evidence of Seaweed and Seagrass Harvesting}


Preservation biases often exclude perishable materials from being unearthed in archaeological contexts, however, this does not necessarily mean that they were not utilized, but only that their remains did not preserve. Although in most cases direct evidence of seaweed and seagrass harvesting has long disappeared from the archaeological record, either because of human consumption, processing, and/or site-specific taphonomic factors, indirect evidence in the form of seaweed associates is a veritable untapped reservoir of data. We suggest that the presence of Type 1 gastropods in archaeological contexts is the result of kelp and seagrass harvesting by humans in the past. The relative percentages of these shells in sites through time may be able to act as proxies for changes in harvesting intensity and potentially provide information regarding fluctuations in kelp and seagrass patches and regional or local environmental changes.

As described in ethnohistoric accounts from Western North America (see section 2.1), the relative ease of drying and storing seaweeds makes them highly valuable as a storable non-meat food item and potential fuel source. Each family, genus, and species of macroalgae contains variable amounts of humanly digestible nutrients, with relative percentages also varying within species due to oceanographic, climatic, and seasonal differences (Floreto and Teshima, 1998; Kaehler and Kennish, 1996; Mabeau and Fleurence, 1993; Rupérez, 2002). The relatively lower protein content and higher dietary fiber content of brown algae (Laminariales and Fucales) in particular (Khotimchenko et al., 2002; Kumar et al., 2008) allows these "sea vegetables" to fulfill this human dietary requirement lacking in protein-rich marine diets. Marine macroalgae could thus serve as a valuable dietary alternative to terrestrial botanical resources, especially to islanders subsisting predominantly on marine resources. Though no firsthand accounts of Channel Islanders utilizing kelp for food survive, it is imperative to bear in mind that a lack of 
direct ethnographic information is anything but definitive. Furthermore, the rich record of coastal people using similar marine resources north and south of the Channel Islands (see section 2.1), where it is similarly plentiful, suggests their possible use by analogy. The bountiful resources provided by lush kelp forests along the Circum-Pacific Coast likely acted as a veritable ocean "highway" (Erlandson et al. 2007), dispensing similar suites of marine resources and coastal habitats as humans ventured further south into the Americas.

\subsection{Paleo-environmental Implications}

This study highlights the potential utility of identifying and analyzing all shells found in archaeological middens as a suite of species somewhat akin to a fossil assemblage, albeit an archaeologically biased assemblage. While clearly not equivalent to a naturally accumulated death assemblage, the addition of 76 taxa to the frequently analyzed suite of larger dietary mollusks provides the best data set possible for reconstructing the littoral paleo-ecology of coastal areas frequented by humans in the past, especially in the absence of naturally accumulated fossil records. Although we suggest this as a tentative hypothesis, it has been proposed by environmental scientists that the often ignored, small, non-dietary shells in archaeological middens are the most useful for paleoenvironmental reconstructions (LimondinLozouet et al. 2013:62).

Type 4 species can contribute to our understanding of intertidal paleoecology and in some cases the health of local kelp patches. Offshore kelp beds, and Macrocystis in particular, can be a limiting factor to widespread larval dispersal of intertidal dwelling limpets, as they can decrease currents and wave action in its immediate surroundings (Turner 2003; Shanks et al. i.p.). This links the presence of offshore kelp beds to higher local settlement for limpets living on rocks in the intertidal zone, and suggests that diminishing kelp beds could result in reduced local 
populations for these boulder dwelling species and vice versa. Shanks et al. (i.p.) found a significant correlation between local recruitment of Lottia scabra, an intertidal rock dwelling limpet, and the presence of Macrocystis in the intertidal. In addition, Graham's (2004) study of associated taxa in southern California kelp forests found that several carnivorous mollusks (often found on rocks and boulders) were observed significantly more often in kelp forested habitats over deforested areas. While these species are not direct kelp or seagrass associates in the sense that they do not live directly on marine vegetation, they have a strong association with kelp forest habitats and their presence or absence through time could speak to the relative health of local kelp forest patches. Carnivorous species identified by Graham (2004) and found in the assemblages discussed here include Fusinus kobelti, Homalopoma luridum, and Pseudomelatoma torosa. In addition, the predatory Conus californicus, was found by North (1971) to be common in Southern California kelp beds even though it is not a direct kelp associate. Naturally, a wide range of biological, ecological, and environmental factors intersect and must be teased apart to reach a conclusive understanding of what is causing shifts in taxonomic richness and species density. Though this is beyond the scope of this paper, we believe it is an interesting possibility requiring further investigation.

\subsection{Methodological and Ecological Implications: Human Impacts}

Although temporal scales for archaeological assemblages are often longer than ideal for ecological studies, shell middens around the globe contain substantial evidence that human harvesters impacted the size structure and relative abundances of exploited populations (Jerardino 1997, 2010; Langejans et al. 2012; Mannino and Thomas 2002; Parkington, 2008; Sealy and Galimberti 2011; Tonner 2005; and others). Nevertheless, factors such as species interactions and trophic level dynamics, and changes in oceanographic temperature and sea level 
complicate anthropogenic induced effects of predation and its clues in the archaeological record (see Bailey and Milner 2008; Dayton et al. 1998; Mannino and Thomas 2002).

Human harvesters in intertidal shellfish beds exert a disproportionate effect on rocky shore communities, significantly altering community dynamics as they collect much larger quantities with higher efficiency than other predators (Adessi 1994; Castilla and Durán 1985; Hockey 1994; Moreno et al. 1984; Oliva and Castilla 1986; Ortega 1987). Although selective exploitation of shellfish in rocky intertidal areas can disrupt space mosaics causing significant changes in community structure, these disturbances are not permanent due to the dynamic nature of biological systems, and major changes may occur again when exploitation ceases or switches to another species (Durán and Castilla 1989; Dye 1992; Hockey and Bosman 1986; Lasiak 1991; Moreno et al. 1984, 1986; Oliva and Castilla 1986). In addition to impacts on exploited populations, non-targeted species can also experience indirect effects, such as altered size structures and alterations in species abundances (e.g., Roy et al. 2003). Lindberg et al. (1998) found that when the large and dietarily important limpet, Lottia gigantea, was removed from intertidal boulders, small limpets, such as $L$. scabra, often increased in density. Suggesting that increases in relative abundances of small, non-dietary limpets may also be indicative of intensive human harvesting of larger dietary species.

We suggest that small, non-dietary shells in coastal middens can contribute to a more complete (though not exhaustive) understanding of nearshore community composition and dynamics in the past. By identifying the full suite of represented species in archaeological assemblages, it is possible to infer the state of littoral ecosystems and how they shifted through time, allowing us to better reconstruct possible consequences of human predation in these heavily utilized primary resource habitats. Relative percentages of small gastropods can be used 
in conjunction with reduced abundances and shell size changes of purposefully harvested shellfish to support or negate perceived impacts. The presence of these species as well as their detailed analysis (e.g., stable isotope geochemistry, trace elemental analysis, etc.) can provide the environmental parameters against which anthropogenic impacts of marine resources can be compared. We believe that when all shells, including small, non-dietary mollusks, uncovered in coastal midden deposits are analyzed together as a suite of taxa, a more complete picture of the paleo-community is attainable. Adding ancillary mollusks can increase taxonomic richness counts from 10-20 dietary taxa to close to 100 total taxa as seen at CA-SMI-603 (Ainis 2012), thus greatly increasing the potential for nearshore reconstructions. Reconstructing the most representative population possible can contribute to our understanding of how these ecosystems were affected and potentially managed by humans in the past.

\section{Conclusions}

This study demonstrates some of the types of data that can be gleaned from non-dietary shells accidentally incorporated in archaeological shell middens and suggests tentative implications for further investigation. The behavioral implications of this study suggest islanders from San Nicolas and San Miguel were utilizing very similar harvesting strategies despite typological, spatial, and temporal differences between sites, conforming to regional patterns and similar nearshore ecology on both islands. The methodological significance of this study lies in the discovery that small, non-dietary shells in coastal middens have stories to tell. Although they may not contain information on direct subsistence strategies, they can be used to infer harvesting of marine resources like kelps and seagrasses and potentially inform us on the community structure and relative health of local kelp forests and intertidal communities in the past. We have demonstrated that small gastropods can be used to infer kelp and seagrass harvesting; the 
presence of shellfish species whose shells were utilized and therefore no longer present in an archaeological assemblage; and tentatively support environmental data demonstrating shifts in kelp forest productivity. Furthermore, we suggest the possibility that ancillary shells may be used to signal paleoenvironmental factors such as changes in climate and sea surface temperature and nearshore ecology, though distinguishing between these interrelated factors is beyond the scope of this paper.

Whereas taxonomic identifications presented here are limited to the southern California region, the concept of identifying small shells and investigating the ecological implications they may contain is not limited to any one region or area. The identification of numerous seaweed and seagrass associates is a step towards better understanding the use of these highly perishable but extremely useful resources in the past. The application of these types of data has the potential to reveal new patterns and more in-depth understandings of coastal lifeways around the globe. 


\section{Acknowledgments}

Funding for this research was provided by the U.S. Navy, California State University, Los Angeles, the University of Oregon, and the University of Rhode Island. We thank students at the California State University, Los Angeles California Coastal Archaeology Lab for help with the initial sort of faunal materials from CA-SNI-40. Our gratitude and appreciation is extended to

Jon M. Erlandson for discussions on this topic and for sharing helpful insights. We are grateful to Frances J. White for guidance with statistical analyses. Special thanks to Lindsey T. Groves, Collections Manager, Malacology Department Natural History Museum, Los Angeles County, for access to collections. We are grateful to Lisa Thomas-Barnett and Steven J. Schwartz for help with logistics. Finally, we thank the reviewers and editors of the Journal of Archaeological Science for providing constructive feedback and greatly improving this manuscript. 


\section{References}

Aaronson, S. 1986. A role for algae as human food in antiquity. Food and Foodways 1:311-315.

Abbott, I. A., Hollenberg, G. J., 1976. Marine Algae of California. Stanford University Press, Stanford, California.

Addessi, L., 1994. Human disturbance and long-term changes on a rocky intertidal community. Ecological Applications 4(4):786-797.

Ager, T.A., Ager, L.P., 1980. Ethnobotany of the Eskimos of Nelson Island, Alaska. Arctic Anthropology 17(1):26-48.

Ainis, A. F., 2012. Eight thousand years at Bay Point: archaeology and historical ecology at Cave of the Chimneys (CA-SMI-603), San Miguel Island, California. M.A. Thesis, California State University, Los Angeles.

Ainis, A. F., Vellanoweth, R. L., 2012. Expanding the chronology for the extinct giant island deer mouse (Peromyscus nesodytes) on San Miguel Island, California. Journal of Island and Coastal Archaeology 7(1):146-152.

Ainis, A. F., Vellanoweth, R. L., Davis, T.W., Erlandson, J.M., Rick, T.C., 2011. Changes in marine subsistence on San Miguel Island from 8,500 to 2,400 years ago: analysis of bulk samples from Cave of the Chimneys (CA-SMI-603). Journal of California and Great Basin Anthropology 31(1):59-79.

Allen, R.K., 1969. Common Intertidal Invertebrates of Southern California. Peek Publications, Palo Alto, California.

Avery, G., Halkett, D., Orton, J., Steele, T., Tusenius, M., Klein, R., 2008. The Ysterfontein 1 Middle Stone Age rock shelter and the evolution of coastal foraging. Goodwin Series, vol. 10, Current Themes in Middle Stone Age Research. South African Archaeological Society, pp. 6689.

Bailey, G., Milner, N., 2008. Molluscan archives from European prehistory. BAR International Series 1865:111-113.

Barrière, J., 1969. Les coquilles marines découvertes sur le sol de la cabane acheuléenne du Lazaret. In: de Lumley, H. (Ed.), Une cabane acheuléenne dans la grotte du Lazaret (Nice). Mémoire de la Société Préhistorique de France, vol. 7, pp. 117-118.

Berlin, B., 1973. Folk systematics in relation to biological classification and nomenclature. Annual Review of Ecology and Systematics 4:259-271. 
Braje, T. J., D. J. Kennett, J. M. Erlandson, and B. J. Culleton, 2007. Human Impact on Nearshore Shellfish Taxa: A 7,000 Year Record from Santa Rosa Island, California. American Antiquity 72(4):735-756.

Braje, T.J., Rick, T.C., Erlandson, J.M., 2012. A trans-Holocene historical ecological record of shellfish harvesting on California's Northern Channel Islands. Quaternary International 264:109-120.

Braje, T.J., Rick, T.C., DeLong, R.L., Erlandson, J.M., 2011. Resilience and reorganization: archaeology and historical ecology of California Channel Island sea mammals. In: Braje, T.J., Rick, T.C. (Eds.), Seals, Sea Lions, and Sea Otters: Integrating Archaeology and Ecology in the Northeast Pacific. University of California Press, Berkeley, pp. 273-296.

Brandon, J.L., Rokop, F.J., 1985. Life Between the Tides: The Natural History of the Common Seashore Life of Southern California. American Southwest Publishing Company, San Diego, California.

Carlton, J. T. (Editor), 2007. The Light and Smith Manual: Intertidal Invertebrates from Central California to Oregon, Fourth Edition. University of California Press, Berkeley and Los Angeles, California.

Castilla, J. C., Durán, L. R., 1985. Human exclusion from the intertidal zone of central Chile: the effects on Concholepas concholepas (Gastropoda). Oikos 45:391-399.

Chapman, V.J., Chapman, D.J., 1980. Seaweeds and Their Uses. Chapman and Hall, London.

Claassen, C. 1998. Shells. Cambridge Manuals in Archaeology. Cambridge University Press.

Colonese, A.C., Wilkens, B., 2005. The Malacofauna of the Upper Paleolithic Levels at Grotta della Serratura (Salerno, Southern Italy): Preliminary Data. In Archaeomalacology: Molluscs in Former Environments of Human Behaviour, edited by D.E. Bar-Yosef Mayer, pp. 63-70. Oxford: Oxbow Books.

Colten, R.H., Arnold, J.E., 1998. Prehistoric marine mammal hunting on California's Northern Channel Islands. American Antiquity 63:679-701.

Connolly, T. J., Erlandson, J. M., Norris, S. E., 1995. Early basketry and cordage from Daisy Cave, San Miguel Island, California. American Antiquity 60(2):309-318.

Coyer, J.A., 1986. The mollusk assemblage associated with fronds of giant kelp (Macrocystis pyrifera) off Santa Catalina Island, California. Bulletin of Southern California Academy of Sciences 5(3):129-138. 
Cortés-Sánchez, M., Morales-Muñiz, A., Simón-Vallejo, M.D., Lozano-Francisco, M.C., VeraPeláez, J.L., Finlayson, C., Rodríguez-Vidal, J., Delgado-Huertas, A., Jiménez-Espejo, F.J., Martínez-Ruiz, F., Martínez-Aguirre, M.A., Pascual-Granged, A.J., Bergadà-Zapata, M.M., Gibaja-Bao, J.F., Riquelme-Cantal, J.A., López-Sáez, J.A., Rodrigo-Gámiz, M., Sakai, S., Sugisaki, S., Finlayson, G., Fa, D.A., Bicho, N.F., 2010. Earliest known use of marine resources by Neanderthals. PloS-One 6(9), e24026, pp. 1-15.

Cunnane, S.C., Stewart, K.M. 2010. Human brain evolution: a wetlands scenario. In: Cunnane, S.C., Stewart, K.M. (Eds.), Human Brain Evolution: The Influence of Freshwater and Marine Resources. Wiley-Blackwell, New Jersey, pp. 203-208.

Dawcyzynski, C., Schubert, R., Jahreis, G., 2006. Amino acids, fatty acids, and dietary fiber in edible seaweed products. Food Chemistry 103:891-899.

Dayton, P.K., 1985. Ecology of kelp forest communities. Annual Review of Ecology and Systematics 16:215-245.

Dayton, P.K., Tegner, M.J., Edwards, P.B., Riser, K.L., 1998. Sliding baselines, ghosts, and reduced expectations in kelp forest communities. Ecological Applications 8(2):309-322.

Dillehay, T.D., Ramirez C., Pino, M., Collins, M.B., Rossen, J., Pino-Navarros, J.D., 2008. Monte Verde: Seaweed, food, medicine, and the peopling of South America. Science 320:784786.

Druehl, L., 2000. Pacific Seaweeds: A Guide to Common Seaweeds of the West Coast. Harbour Publishing, Madeira Park, British Columbia, Canada.

Durán, L. R., Castilla, J. C., 1989. Variation and persistence of the middle rocky intertidal community of central Chile, with and without human harvesting. Marine Biology 103:555-562.

Edwards, M.S., 2004. Estimating scale-dependency in disturbance impacts: El Niños and giant kelp forests in the northeast Pacific. Oecologia 138(3):436-447.

Engle, J. M., 1994. Perpsectives on the structure and dynamics of nearshore marine assemblages of the California Channel Islands. In: Halvorson, W. L., Maender, G. J (Eds.), Fourth California Channel Islands Symposium: Update on the Status of Resources. Santa Barbara Museum of Natural History, Santa Barbara California, pp. 13-26.

Erlandson, J.M., 2001. The archaeology of aquatic adaptations: paradigms for a new millennium. Journal of Archaeological Research 9:287-350. 
Erlandson, J.M., 2010. Food for thought: the role of coastlines and aquatic resources in human evolution. In: Cunnane, S.C., Stewart, K.M. (Eds.), Human Brain Evolution: The Influence of Freshwater and Marine Resources. Wiley-Blackwell, New Jersey, pp. 125-136.

Erlandson, J. M., Braje, T. J., Rick, T. C., Jew, N.P, Kennett, D.J., Dwyer, N., Ainis, A.F., Vellanoweth, R. L., Watts, J., 2011a. 10,000 years of human predation and size changes in the owl limpet (Lottia gigantea) on San Miguel Island, California. Journal of Archaeological Science 38:1127-1134.

Erlandson, J. M., Graham, M. H., Bourque, B. J., Corbett, D., Estes, J. A., Steneck, R. S., 2007. The kelp highway hypothesis: marine ecology, the coastal migration theory, and peopling of the Americas. Journal of Island and Coatal Archaeology 2:161-174.

Erlandson, J.M., Rick, T.C., Braje, T.J., 2009. Fishing up the food web?: 12,000 years of maritime subsistence and adaptive adjustments on California's Channel Islands. Pacific Science 63(4):711-724.

Erlandson, J. M., Rick, T. C., Braje, T. J., Casperson, M., Fulfrost, B., Garcia, T., Guthrie, D. A., Jew, N., Moss, M. L., Reeder, L., Watts, J., Willis, L., 2011b. Paleoindian seafaring, shell middens, and maritime technologies on California's Northern Channel Islands. Science 331:1181-1185.

Erlandson, J. M., Rick, T. C., Braje, T. J., Steinberg, A., Vellanoweth, R. L., 2008. Human impacts on ancient shellfish: a 10,000 year record from San Miguel Island, California. Journal of Archaeological Science 35:2144-2152.

Erlandson, J. M., Rick, T. C., Estes, J. A., Graham, M. H., Braje, T. J., Vellanoweth, R. L., 2005. Sea otters, shellfish, and humans: 10,000 years of ecological interaction on San Miguel Island, California. In: Garcelon, D., Schwemm, C. (Eds.), Proceedings of the Sixth Channel Islands Symposium. National Park Service Technical Publication CHIS-05-01, Institute for Wildlife Studies, Arcata, California, pp. 9-21.

Estes, J. A., Steinberg, P. D., 1988. Predation, herbivory, and kelp evolution. Paloebiology 14(1):19-36.

Felger, R. S., Moser, M. B., 1970. Seri use of century plant (Agave). The Kiva 35:159-167.

Felger, R. S., Moser, M. B., 1971. Seri use of mesquite (Prosopis glandulosa var. torreyana). The Kiva 37:53-60.

Felger, R. S., Moser, M. B., 1973. Eelgrass (Zostera marina L.) in the Gulf of California: Discovery of its Nutritional Value by the Seri Indians. Science 181:355-356. 
Felger, R. S., Moser, M. B., 1976. Seri Indian Food Plants: Desert Subsistence without Agriculture. Ecology of Food and Nutrition 5:13-27.

Felger, R.S., Moser, M.B., 1985. People of the Desert and Sea: Ethnobotany of the Seri Indians. University of Arizona Press, Tucson, Arizona.

Felger, R. S., Moser, E. W., Moser, M. B., 1980. Seagrasses in Seri Indian culture. In: Phillips, R. C., McRoy, C. P. (Eds.), Handbook of Seagrass Biology: An Ecosystem Perspective. Garland Press, New York, pp. 261-276.

Fleurence, J. 1999. Seaweeds proteins: biochemical, nutritional aspects and potential uses. Trends in Food Science and Nutrition 10:25-28.

Floreto, E.A.T., Teshima, S. 1998. The fatty acid composition of seaweeds exposed to different levels of light intensity and salinity. Botanica Marina 4:467-481.

Foster, M. S., Schiel, D. R., 1985. The Ecology of Giant Kelp Forests in California: A Community Profile. U.S. Fish and Wildlife Service Biological Report 85(7.2).

Glassow, M.A., 1993. Changes in subsistence on marine resources through 7,000 years of prehistory on Santa Cruz Island. In: Glassow, M.A. (Ed.), Archaeology on the Northern Channel Islands of California. Archives of California Prehistory 34. Coyote Press, Salinas, California, pp. 75-90.

Graham, M.K., 2004. Effects of local deforestation on the diversity and structure of Southern California giant kelp forest food webs. Ecosystems 7:341-357.

Graham, M.H., Dayton, P.K., Erlandson, J.E., 2003. Ice ages and ecological transition on temperate coasts. Trends in Ecology and Evolution 18(1):33-40.

Graham, M.H., Kinlan, B.P., Grosberg, R.K., 2010. Post-glacial redistribution and shifts in productivity of giant kelp forests. Proceedings of the Royal Society B: Biological Sciences 277:399-406.

Guiry, M.D., Blunden, G. 1991. Seaweed Resources in Europe: Uses and Potential. John Wiley and Sons, Chichester, U.K.

Hinton, S., 1987. Seashore Life of Southern California. Revised edition. University of California Press, Berkeley.

Hockey, P.A.R., 1994. Man as component of the littoral predator spectrum: a conceptual overview. In: Siegfried, W. R. (Ed.), Rocky Shores: Exploitation in Chile and South Africa. Ecological Studies, Vol. 103. Springer-Verlag, New York, pp. 17-31. 
Hockey, P.A.R., Bosman, A.L., 1986. Man as an intertidal predator in Transkei: disturbance, community convergence and management of a natural food resource. Oikos 46:3-14.

Hong, D.D, Hien, H.M., Son, P.M. 2007. Seaweeds from Vietnam used for functional food, medicine and biofertilizer. Journal of Applied Phycology 19(6):817-826.

Indegaard, M., Minsaas, J., 1991. Animal and human nutrition. In: Guiry, M.D., Blunden, G. (Eds.), Seaweed Resources in Europe: Uses and Potential. John Wiley and Sons Ltd., Chichester, pp. 21-64.

Ito, K., Hori, K., 1989. Seaweed: chemical composition and potential uses. Food Review International 5:101-144.

Jerardino, A., 1997. Changes in shellfish species composition and mean shell size from a LateHolocene record of the west coast of South Africa. Journal of Archaeological Science 24:10311044.

Jerardino, A., 2010. Prehistoric exploitation of marine resources in Southern Africa with particular reference to shellfish gathering: Opportunities and continuities. Pyrenae 41(1):7-52.

Johnson, D.L., 1973. Landscape evolution on San Miguel Island, California. Ph.D. Dissertation, University of Kansas. UMI, Ann Arbor.

Johnson, J. R., Stafford, T. W., Ajie, H. O., Morris, D. P., 2002. Arlington Springs revisited. In: Browne, D., Mitchell, K., Chaney, H. (Eds.), Proceedings of the Fifth California Islands Symposium. Santa Barbara Museum of Natural History and U.S. Department of the Interior, Santa Barbara, pp. 541-545.

Jones, L.G., 1971. Studies on selected small herbivorous invertebrates inhabiting Macrocystis canopies and holdfasts in Southern California kelp beds. Nova Hedwegia 32:343-367.

Kaehler, S., Kennish, R., 1996. Summer and winter comparisons in the nutritional value of marine macroalgae from Hong Kong. Botanica Marina 39:11-17.

Kennett, D.J., 2005. The Island Chumash: Behavioral Ecology of a Maritime Society. Berkeley: University of California Press.

Khotimchenko, S.V., Vaskovsky, V.E., Titlyanova, T.V., 2002. Fatty acids of marina algae from the Pacific Coast of North California. Botanica Marina 45:17-22.

Klein, R. G., Avery, G., Cruz-Uribe, K., Halkett, D., Parkington, J. E., Steele, T., Volman, T. P., Yates, R., 2004. Ysterfontein 1 Middle Stone Age site, South Africa, and early human exploitation of coastal resources. Proceedings of the National Academy of Sciences 101(16):5708-5715. 
Kumar, C.S., Ganesan, P., Suresh, P.V., Bhaskar, N. 2008. Seaweeds as a source of nutritionally beneficial compounds: A review. Journal of Food Science and Technology 45(1):1-13.

Langejans, G. H. J., Van Niekerk, K.L., Dusseldorp, G.L., Thackeray, J.F., 2012. Middle Stone Age Shellfish Exploitation: Potential Indications for Mass Collecting and Resource Intensification at Blombos Cave and Klasies River, South Africa. Quaternary International 270:80-94.

Lasiak, T., 1991. The susceptibility and/or resistance of rocky littoral molluscs to stock depletion by the indigenous coastal people of Transkei, Southern Africa. Biological Conservation 56:245264.

Lewis, J.R., 1964. The Ecology of Rocky Shores. English Universities Press, London.

Limondin-Lozouet, N., H. Haddoumi, D. Lafèvre, M. Ghamizi, H. Aouraghe, T. Salel. 2013. Holocene mollusk succession from NE Morocco: paleoenvironmental reconstruction and biogeographical implication. Quaternary International 302:61-76.

Lindberg, D.R., 1976. Marine plant limpets of the northern Pacific: Neogene phylogeny and zoogeography. Western Society of Malacologists Annual Report 9:22-25.

Little, C., Williams, G.A., Trowbridge, C.D., 2009. The Biology of Rocky Shores. Second Edition. Oxford University Press, New York.

Mabeau, S., Fleurence, J., 1993. Seaweed in food products: Biochemical and nutritional aspects. Trends in Food Science and Technology 4:103-107.

MacArtain, P., Gill, C.I., Brooks, M., Campbell, R., Rowland, I.R., 2007. Nutritional value of edible seaweeds. Nutritional Review 65:535-543.

Mann, K.H., 1973. Seaweeds: their productivity and strategy for growth. Science 182:975-981.

Mannino, M.A., Thomas, K.D., 2002. Depletion of a resource? The impact of prehistoric human foraging on intertidal mollusc communities and its significance for human settlement, mobility and dispersal. World Archaeology 33(3):452-474.

Marean , C.W., Bar-Matthewsm M., Bernachez, J., Fisher, E., Goldberg, P., Herries, A.I.R., Jacobs, Z., Jerardino, A., Karkanas, P., Minichillo., T., Nilssen, P., Thompson, E., Watts, I., Williams, H., 2007. Early human use of marine resources and pigments in South Africa during the middle Pleistocene. Nature 449:905-908.

McLean, J.H., 1978. Marine Shells of Southern California. Natural History Museum of Los Angeles County, Los Angeles, California. 
McRoy, C.P., Helfferich, C., 1980. Applied aspects of seagrasses. In: Phillips, R.C., McRoy, C.P. (Eds.), Handbook of Seagrass Biology: An Ecosystem Perspective. Garland Publishing, New York, pp. 297-344.

Mondragon, J., Mondragon, J., 2003. Seaweeds of the Pacific Coast: Common Marine Algae from Alaska to Baja California. Sea Challengers, Monterey, California.

Moreno, C.A., Luneke, K.M., Lepez, M.I., 1986. The response of an intertidal Concholepas concholepas (Gastropoda) population to protection from man in southern Chile and the effects on benthic sessile assemblages. Oikos 46:359-364.

Moreno, C.A., Sutherland, J. P., Jara, H. F., 1984. Man as a predator in the intertidal zone of Southern Chile. Oikos 42:155-160.

Morris, P. A., 1966. A Field Guide to Pacific Coast Shells, Second Edition. Houghton Mifflin Company, Boston.

Morris, R. H., Abbott, D. P., Haderlie, E. C., 1980. Intertidal Invertebrates of California. Stanford University Press, Stanford, California.

Mouritsen, O. G., 2013. Seaweeds: Edible, Available and Sustainable. The University of Chicago Press, Chicago.

Needles, L.A., Wendt, D.E., 2013. Big changes to a small bay: introduced species and long-term compositional shifts to the fouling community of Morro Bay (CA). Biological Invasions 15:1231-1251.

Nisizawa, J., Noda, H., Kikuchi, R., Watanabe, T., 1987. The main seaweed foods of Japan. Hydrobiologia 151/152:5-29.

North, W.J., 1971. The biology of giant kelp beds (Macrocystis) in California: introduction and background. Nova Hedwegia 32:1-68.

Oliva, D., Castilla, J. C., 1986. the effect of human exclusion on the population structure of the key-hole limpets Fissurella crassa and F. limbata on the coast of Central Chile. Pubblicazioni della Stazione Zoologica di Napoli I: Marine Ecology 7:201-217.

Ortega, S., 1987. The effect of human predation on the size distribution of Siphonaria gigas on the Pacific Coast of Costa Rica. The Veliger 19:251-255.

Parkington, J.E., 2008. Limpet sizes in Stone Age archaeological contexts at the Cape, South Africa: changing environments or human impact. In: Antczac, A., Ciprini, R. (Eds.), Early Human Impact on Mega-molluscs. Archaeo-Press, Oxford. BAR International Series 1865:175184. 
Photos-Jones, E., Smith, B.B., Hall, A.J., Jones, R.E., 2007. On the intent to make cramp: an interpretation of vitreous seaweed cremation 'waste' from prehistoric burial sites in Orkney, Scotland. Oxford Journal of Archaeology 26(1):1-23.

Ramos, J., Domínguez-Bella, S., Cantillo, J.J., Soriguer, M., Pérez, M., Hernando, J., Vijande, E., Zabala, C., Clemente, I, Bernal, D., 2011. Marine resources exploitation by Paleolithic hunter-fisher-gatherers and Neolithic tribal societies in the historical region of the Strait of Gibraltar. Quaternary International 239:104-111.

Rehder, H. A., 1981. The Audubon Society Field Guide to North American Seashells. Alfred A. Knopf, New York.

Reinman, F.M., Townsend, S.J., 1960. Six Burial Sites on San Nicolas Island. Archaeological Survey Annual Report 2. University of California, Los Angeles.

Reitz, E.J., Wing, E.S., 2008. Zooarchaeology. Second Edition. Cambridge Manuals in Archaeology. Cambridge University Press, New York.

Rick, T.C., 2011. Weathering the Storm: Coastal Subsistence and Ecological Resilience on Late Holocene Santa Rosa Island. Quaternary International 239:135-146.

Rick, T. C., Erlandson, J. M., 2012. Kelp forests, coastal migrations, and the younger dryas: late Pleistocene and earliest Holocene human settlement, subsistence, and ecology on California's Channel Islands. In: Eren, M. I. (Ed.), Hunter-Gatherer Behavior: Human Response during the Younger Dryas. Left Coast Press, Walnut Creek, California, pp. 79-110.

Rick, T. C., Erlandson, J. M., Braje, T.J., Estes, J.E., Graham, M.H., Vellanoweth, R. L., 2008. Historical ecology and human impacts on coastal ecosystems of the Santa Barbara Channel region, California. In: Rick, T. C., Erlandson, J. M. (Eds.), Human Impacts on Ancient Marine Ecosystems: A Global Perspective. University of California Press, Berkeley, pp. 77-101.

Rick, T. C., Erlandson, J. M., Vellanoweth, R. L., Braje, T.J., 2005a. From Pleistocene mariners to complex hunter-gatherers: the archaeology of the California Channel Islands. Journal of World Prehistory 19:169-228.

Rick, T. C., Vellanoweth, R. L., Erlandson, J. M., 2005b. Early Holocene vertebrate fauna from Cave of the Chimneys (CA-SMI-603), San Miguel Island, California: preliminary results. Proceedings of the Society for California Archaeology 18:302-306.

Ricketts, E., Calvin, J., Hedgpeth, J., 1985. Between Pacific Tides. Fifth Edition. California Stanford University Press, Palo Alto. 
Rosenthal, R.J., Clarke, W.D., Dayton, P.K., 1974. Ecology and natural history of a strand of giant kelp, Macrocystis pyrifera, off Del Mar, California. Fishery Bulletin 72:670-684.

Roy, K., Collins, A.G., Begovic, E., Engle, J.M., 2003. Anthropogenic impacts and historical decline in body size of rocky intertidal gastropods in southern California. Ecology Letters 6:205211.

Rupérez, P., 2002. Mineral content of edible marine seaweeds. Food Chemistry 79:23-26.

Scagel, R. F., 1961. Marine Plant Resources of British Columbia. Fisheries Research Board of Canada Bulletin No. 127.

Schoenherr, A.A., Feldmeth, C.R., Emerson, M.J., 1999. Natural History of the Islands of California. University of California Press, Berkeley.

Sealy, J., Galimberti, M., 2011. Shellfishing and the Interpretation of Shellfish Sizes in the Middle and Later Stone Ages of South Africa. In Trekking the Shore: Changing Coastlines and the Antiquity of Coastal Settlement, edited by N. F. Bicho, J. A. Haws and L. G. Davis, pp. 405420. New York: Springer.

Shanks. A., Walser, A., Shanks, L., i.p. Population structure, northern range limit, and recruitment variation in the intertidal limpet Lottia scabra. Marine Biology (Accepted: 25 January 2014).

Sheridan, T.E., Felger, R.S., 1977. Indian utilization of eelgrass (Zostera marina) in northwestern Mexico: Spanish colonial record. The Kiva 43:89-92.

Sokal, R.R., Rohlf, F.J., 2012. Biometry: The Principles and Practice of Statistics in Biological Research. Fourth Edition. W.H. Freeman and Company, New York.

Stephenson, T.A., Stephenson, A., 1972. Life between Tidemarks on Rocky Shores. W.H. Freeman and Company, San Francisco, California.

Stiner, M.C., 1994. Honor Among Thieves: A Zooarchaeological Study of Neandertal Ecology. Princeton University Press, Princeton.

Stiner, M. C., 1999. Paleolithic mollusk exploitation at Riparo Mochi (Balzi Rossi, Italy): Food and ornaments from the Aurignacian through Epigravettian. Antiquity 73(282):735-754.

Stuiver, M., Reimer, P.J., 1993. Extended ${ }^{14} \mathrm{C}$ data base and revised Calib $3.0{ }^{14} \mathrm{C}$ Age calibration program. Radiocarbon 28:980-1021.

Stuiver, M., Reimer, P.J., 1999. Calib 4.1 Radiocarbon Calibration Program 1999. Quaternary Isotope Lab, University of Washington, Seattle. 
Szabó, K., Amesbury, J. R., 2011. Molluscs in a world of islands: The use of shellfish as a food resource in the tropical island Asia-Pacific region. Quaternary International 239:8-18.

Tonner, T.W.W., 2005. Later stone age shellfishing behaviour at Dunefield Midden (Western Cape, South Africa). Journal of Archaeological Science 32:1390-1407.

Turner, J.S., 2003. Trace fossils and extended organisms: a physiological perspective. Paleogeography, Paleoclimatology, Paleoecology 192:15-31.

Turner, N.J., 1995. Food Plants of Coastal First Peoples. Royal British Columbia Museum Handbook, UBC Press, Vancouver, Canada.

Turner, N.J., 2003. The ethnobotany of edible seaweed (Porphyra abbottae and related species; Rhodophyta: Bangiales) and its use by First Nations on the Pacific Coast of Canada. Canadian Journal of Botany 81:283-293.

Turner, N.J., Bell, M.A.M., 1973. The ethnobotany of the Southern Kwakiutl Indians of British Columbia. Economic Botany 27(3):257-310.

Turner, N.J., Loewen, D.C., 1998. The original "free trade:" exchange of botanical products and associated plant knowledge in northwestern North America. Anthropologica XL:49-70.

Vellanoweth, R. L., Lambright, M., Erlandson, J. M., Rick, T. C., 2003. Early New World maritime technologies: sea grass cordage, shell beads, and a bone tool from Cave of the Chimneys, San Miguel Islands, California, USA. Journal of Archaeological Science 30:11611173.

Vellanoweth, R. L., Rick, T.C., Erlandson, J.M., 2002. Middle and Late Holocene maritime adaptations on northeastern San Miguel Island, California. In: Browne, D., Mitchell, K., Chaney, H. (Eds.), Proceedings of the Fifth Channel Islands Symposium. Santa Barbara Museum of Natural History, Santa Barbara, California, pp. 607-614. 
Table 1. A Radiocarbon Chronology for Cave of the Chimneys (CA-SMI-603).

\begin{tabular}{|c|c|c|c|c|c|}
\hline $\begin{array}{l}\text { Unit } 1 \\
\text { Stratum/Level }\end{array}$ & Lab number & Material dated & $\begin{array}{l}\text { Uncorrected } \\
{ }^{14} \mathrm{C} \text { age (RYBP) }\end{array}$ & $\begin{array}{l}{ }^{13} \mathrm{C} /{ }^{12} \mathrm{C} \\
\text { Adjusted }\end{array}$ & $\begin{array}{l}\text { Adjusted age range } \\
\text { (cal BP, } 1 \text { sigma) }\end{array}$ \\
\hline I & OS-85199 & Marine Shell & N/A & $1700 \pm 25$ & $1067: 956$ \\
\hline II / 1 & OS-85200 & Marine Shell & N/A & $2800 \pm 25$ & $2311: 2191$ \\
\hline II / 2 & OS-85201 & Marine Shell & N/A & $2930 \pm 25$ & $2461: 2331$ \\
\hline II & Beta-115556 & Marine Shell & $2550 \pm 60$ & $2980 \pm 60$ & $2575: 2352$ \\
\hline II / 3 & OS-85202 & Marine Shell & N/A & $3560 \pm 25$ & $3268: 3128$ \\
\hline II / 4 & OS-85203 & Marine Shell & N/A & $4010 \pm 25$ & $3804: 3672$ \\
\hline III & Beta-115557 & Marine Shell & $3830 \pm 70$ & $4270 \pm 70$ & $4188: 3955$ \\
\hline $\begin{array}{l}\text { Probe B: } \\
15-20 \mathrm{~cm}\end{array}$ & Beta-12454 & Marine Shell & N/A & $4430 \pm 60$ & $4403: 4207$ \\
\hline IV & Beta-115558 & Marine Shell & $4010 \pm 70$ & $4450 \pm 70$ & $4426: 4208$ \\
\hline V & Beta-115559 & Marine Shell & $4030 \pm 60$ & $4480 \pm 60$ & $4445: 4245$ \\
\hline $\begin{array}{l}\text { Probe B: } \\
15-20 \mathrm{~cm}\end{array}$ & Beta-14364A & Charcoal & N/A & $3930 \pm 60$ & $4497: 4257$ \\
\hline $\begin{array}{l}\text { Probe B: } \\
35-40 \mathrm{~cm}\end{array}$ & Beta-14367A & Charcoal & N/A & $3940 \pm 60$ & $4512: 4292$ \\
\hline $\begin{array}{l}\text { Probe B: } \\
35-40 \mathrm{~cm}\end{array}$ & Beta-12455A & Marine Shell & N/A & $4560 \pm 60$ & $4841: 4683$ \\
\hline VI & Beta-129099 & Olivella bead & $6890 \pm 70$ & $7300 \pm 70$ & $7623: 7483$ \\
\hline VI & Beta-136695 & Marine Shell & $7440 \pm 60$ & $7300 \pm 60$ & $8180: 8019$ \\
\hline VI & Beta-122712 & Marine Shell & $7690 \pm 80$ & $8120 \pm 80$ & $8456: 8268$ \\
\hline VII & Beta-122713 & Marine Shell & $7220 \pm 70$ & $7650 \pm 70$ & $7963: 7805$ \\
\hline VII & Beta-136696 & Marine Shell & $7310 \pm 80$ & $7740 \pm 80$ & $8070: 7876$ \\
\hline
\end{tabular}

Beta dates compiled from Kennett (1998), Vellanoweth et al. (2002), and Vellanoweth et al. (2003). OS dates compiled from Ainis and Vellanoweth (2012). Dates were calibrated via Stuiver and Reimer's (1993, 1999) Calib 6.0.1 using a $\Delta \mathrm{R}$ of $225 \pm 35$ years, and adjusted according to Hughen et al. (2004). ${ }^{13} \mathrm{C} /{ }^{12} \mathrm{C}$ ratios were determined by the radiocarbon lab. 
Table 2. A Radiocarbon Chronology for CA-SNI-40.

\begin{tabular}{|c|c|c|c|c|c|c|c|}
\hline \multirow{2}{*}{ Locus } & \multirow{2}{*}{ Unit } & \multirow[b]{2}{*}{$\begin{array}{l}\text { Stratum/ } \\
\text { Level }\end{array}$} & \multirow[b]{2}{*}{$\begin{array}{c}\text { Lab } \\
\text { Number }\end{array}$} & \multirow{2}{*}{ Material Dated } & \multirow{2}{*}{$\begin{array}{c}\text { Un-calibrated } \\
{ }^{14} \mathrm{C} \text { Age } \\
\text { Range } \\
\text { (RYBP) }\end{array}$} & \multicolumn{2}{|c|}{ Calibrated Age Range (BP) } \\
\hline & & & & & & One Sigma: & Two Sigma: \\
\hline Auger & \#4 & - & OS-105788 & S. bifurcatus & $4720 \pm 45$ & $4788-4617$ & $4821-4523$ \\
\hline A & 1 & IA/ 1 & OS-85189 & H. cracherodii & $4360 \pm 30$ & $4280-4125$ & $4368-4064$ \\
\hline A & 2 & $\mathrm{I} / 1$ & OS-85188 & H. rufescens & $4370 \pm 20$ & $4282-4141$ & $4357-4082$ \\
\hline A & 2 & IIA/1 & OS-85191 & H. cracherodii & $4380 \pm 35$ & $4308-4142$ & $4385-4081$ \\
\hline $\mathrm{B}$ & 3 & II/1 & OS-85195 & H. cracherodii & $4280 \pm 30$ & $4147-3995$ & $4232-3935$ \\
\hline $\mathrm{B}$ & $3 \mathrm{~A}$ & Pit Feature & OS-85192 & H. cracherodii & $4390 \pm 30$ & $4318-4157$ & 4389-4099 \\
\hline $\mathrm{C}$ & 5 & $\mathrm{I} / 2$ & OS-85197 & H. cracherodii & $4340 \pm 35$ & $4242-4083$ & $4343-4004$ \\
\hline $\mathrm{C}$ & 6 & $\begin{array}{l}\text { Ochre } \\
\text { Feature }\end{array}$ & OS-85196 & H. cracherodii & $4130 \pm 30$ & $3953-3821$ & $4037-3728$ \\
\hline $\mathrm{C}$ & 6 & $\mathrm{IIIO} / 2$ & OS-96261 & H. cracherodii & $4120 \pm 25$ & $3941-3813$ & $3995-3714$ \\
\hline $\mathrm{C}$ & $5 / 6 \mathrm{~A}$ & IIHR/1 & OS-105787 & H. rufescens & $4440 \pm 40$ & $4392-4238$ & $4466-4138$ \\
\hline $\mathrm{C}$ & $5 / 6 \mathrm{~A}$ & $\mathrm{IIHC} / 1$ & OS-105782 & H. cracherodii & $4440 \pm 30$ & $4386-4247$ & $4427-4151$ \\
\hline $\mathrm{C}$ & $5 / 6 \mathrm{~B}$ & IU/1 & OS-96260 & H. cracherodii & $4120 \pm 25$ & $3941-3813$ & $3995-3714$ \\
\hline $\mathrm{D}$ & 7 & $\mathrm{I} / 4$ & OS-85190 & H. cracherodii & $4070 \pm 25$ & $3861-3726$ & $3931-3671$ \\
\hline $\mathrm{E}$ & 9 & IA/1 & OS-85194 & H. cracherodii & $4150 \pm 30$ & $3969-3836$ & $4064-3774$ \\
\hline $\mathrm{E}$ & 11 & $\begin{array}{c}\text { IIHC/1 } \\
\text { (Dark } \\
\text { Feature) }\end{array}$ & OS-105783 & M. californianus & $4440 \pm 30$ & $4341-4182$ & $4401-4118$ \\
\hline $\mathrm{E}$ & 12 & IA/1 & OS-85193 & H. cracherodii & $4070 \pm 35$ & $3867-3719$ & $3951-3661$ \\
\hline $\mathrm{E}$ & 12 & II/1 & OS-85198 & Diomedeidae & $4480 \pm 30$ & $4423-4286$ & $4501-4223$ \\
\hline $\mathrm{E}$ & 12 & IIHC/trans & OS-105786 & H. cracherodii & $4370 \pm 40$ & $4303-4128$ & $4389-4064$ \\
\hline $\mathrm{E}$ & $12 \mathrm{~A}$ & IIHC/SU/1 & OS-96262 & H. cracherodii & $4170 \pm 25$ & $3982-3866$ & $4057-3830$ \\
\hline $\mathrm{E}$ & $12 \mathrm{~A}$ & IIHR & OS-105789 & H. cracherodii & $4180 \pm 25$ & $4011-3871$ & $4078-3826$ \\
\hline $\mathrm{E}$ & $10 \mathrm{~A} / 12 \mathrm{~A}$ & $\begin{array}{c}\text { Ash } \\
\text { Feature }\end{array}$ & OS-105784 & Chlorostoma sp. & $4300 \pm 30$ & $4206-4050$ & $4264-3961$ \\
\hline $\mathrm{E}$ & $10 \mathrm{~A} / 12 \mathrm{~A}$ & $\begin{array}{c}\text { Ash } \\
\text { Feature }\end{array}$ & OS-105785 & M. californianus & $4220 \pm 30$ & $4072-3930$ & $4140-3862$ \\
\hline $\mathrm{E}$ & $10 \mathrm{~A} / 12 \mathrm{~A}$ & $\begin{array}{c}\text { Ash } \\
\text { Feature }\end{array}$ & OS-96263 & H. cracherodii & $4230 \pm 35$ & $4085-3934$ & $4160-3859$ \\
\hline
\end{tabular}

Dates were calibrated via Stuiver and Reimer $(1993,1999)$ Calib 6.0.1 using a $\Delta \mathrm{R}$ of $225 \pm 35$ years, and adjusted according to Hughen et al. 2004. 
Table 3. Categorical Definitions of Non-Dietary Gastropods in Archaeological Shell Middens.

\begin{tabular}{|c|c|c|c|c|c|c|}
\hline Category & Characterization & $\begin{array}{c}\text { Habitat/ } \\
\text { Substrate }\end{array}$ & $\begin{array}{c}\text { Definition and } \\
\text { Association }\end{array}$ & Inference & $\begin{array}{c}\text { CA-SMI-603 } \\
\text { MNI }\end{array}$ & $\begin{array}{c}\text { CA-SMI-40 } \\
\text { MNI }\end{array}$ \\
\hline Type 1 & $\begin{array}{l}\text { Seaweed and } \\
\text { Seagrass } \\
\text { Associates }\end{array}$ & $\begin{array}{l}\text { Kelpbeds and } \\
\text { seagrass } \\
\text { meadows }\end{array}$ & $\begin{array}{l}\text { Taxa that live on, or are } \\
\text { closely associated with, } \\
\text { marine macrophytes; } \\
\text { some taxa are species } \\
\text { specific to certain kelps } \\
\text { and seagrasses. }\end{array}$ & $\begin{array}{l}\text { Can be used to infer harvesting of } \\
\text { marine macrophytes and } \\
\text { transportation of marine vegetation } \\
\text { back to the archaeological site. }\end{array}$ & $852(27 \%)$ & $234(22 \%)$ \\
\hline Type 2 & $\begin{array}{c}\text { Sand and Gravel } \\
\text { Dwellers }\end{array}$ & $\begin{array}{l}\text { Coarse sand } \\
\text { and gravely } \\
\text { substrate } \\
\text { underlying } \\
\text { kelpbeds and } \\
\text { seagrass } \\
\text { meadows }\end{array}$ & $\begin{array}{l}\text { Taxa that live in the } \\
\text { coarse sand and gravely } \\
\text { substrate often } \\
\text { underlying kelpbeds and } \\
\text { seagrass meadows; some } \\
\text { are also often found on } \\
\text { the base and holdfasts of } \\
\text { kelps and seagrasses. }\end{array}$ & $\begin{array}{c}\text { Possible use as indicators of } \\
\text { marine macrophyte harvesting by } \\
\text { pulling up entire stocks including } \\
\text { bases and holdfasts. }\end{array}$ & $32(1 \%)$ & $23(<2 \%)$ \\
\hline Type 3 & $\begin{array}{c}\text { Mollusk } \\
\text { Commensals }\end{array}$ & $\begin{array}{l}\text { Live on other } \\
\text { larger } \\
\text { shellfish in the } \\
\text { intertidal zone }\end{array}$ & $\begin{array}{l}\text { Taxa that are known } \\
\text { associates of other } \\
\text { mollusks in the intertidal } \\
\text { zone; some are found on } \\
\text { a variety of taxa and } \\
\text { others are species } \\
\text { specific. }\end{array}$ & $\begin{array}{l}\text { Can be useful in instances where } \\
\text { the host shell is no longer present } \\
\text { because it was used to manufacture } \\
\text { tools or ornaments. }\end{array}$ & $1,392(44 \%)$ & $432(40 \%)$ \\
\hline Type 4 & $\begin{array}{c}\text { Rock and Boulder } \\
\text { Dwellers }\end{array}$ & $\begin{array}{l}\text { Rocks and } \\
\text { boulders in } \\
\text { upper } \\
\text { intertidal to } \\
\text { sublittoral } \\
\text { zones }\end{array}$ & $\begin{array}{l}\text { Taxa that live on large } \\
\text { rocks and boulders at } \\
\text { various depths in the } \\
\text { intertidal zone; possible } \\
\text { associations with all } \\
\text { species of shellfish } \\
\text { gathered for subsistence } \\
\text { purposes. }\end{array}$ & $\begin{array}{l}\text { Possible explanations for the } \\
\text { presence of these shells include: } \\
\text { scraping of rocks and boulders for } \\
\text { mussels, turban snails, etc.; } \\
\text { harvesting clusters of shells rather } \\
\text { than individuals; accidental } \\
\text { dislodging by strands of kelp and } \\
\text { seagrasses that were dragged and } \\
\text { collected in the intertidal zone. }\end{array}$ & $1,908(60 \%)$ & $741(69 \%)$ \\
\hline
\end{tabular}


Table 4. Ecological Profiles for Mollusk Taxa.

\begin{tabular}{|c|c|c|c|c|c|}
\hline $\begin{array}{c}\text { Scientific } \\
\text { Name }\end{array}$ & $\begin{array}{c}\text { Common } \\
\text { Name }\end{array}$ & $\begin{array}{c}\text { Category/Type } \\
\text { (see Table 3) }\end{array}$ & Habitat Zone & $\begin{array}{c}\text { Habitat Notes and } \\
\text { Associations } \\
\end{array}$ & $\begin{array}{l}\text { Trophic Type and } \\
\text { Food Preference }\end{array}$ \\
\hline $\begin{array}{l}\text { Acanthinucella } \\
\text { (Acanthina) } \\
\text { punctulata }\end{array}$ & $\begin{array}{l}\text { Spotted thorn } \\
\text { drupe }\end{array}$ & 1,2 & $\begin{array}{l}\text { intertidal and } \\
\text { sublittoral }\end{array}$ & $\begin{array}{c}\text { clean coarse sand among eelgrass } \\
(\text { Zostera }) \text {, coralline algae, and } \\
\text { rocks }\end{array}$ & $\begin{array}{l}\text { predators - primarily } \\
\text { eats Littorines }\end{array}$ \\
\hline Acmaea mitra & Whitecap limpet & 3,4 & $\begin{array}{c}\text { low intertidal, } \\
\text { subtidal }\end{array}$ & low intertidal/pools & $\begin{array}{l}\text { herbivore - eats } \\
\text { encrusting algae } \\
\text { Lithothamnion, } \\
\text { Lithophyllum }\end{array}$ \\
\hline $\begin{array}{c}\text { Acteocina } \\
\text { culcitella }\end{array}$ & $\begin{array}{l}\text { Pillow barrel- } \\
\text { bubble, Western } \\
\text { barrel-bubble }\end{array}$ & 2 & $\begin{array}{c}\text { high intertidal to } \\
46 \mathrm{~m}\end{array}$ & bays and lagoons in sand and mud & $\begin{array}{l}\text { predator - eats } \\
\text { foraminifera }\end{array}$ \\
\hline Alia carinata & $\begin{array}{l}\text { Carinate dove } \\
\text { snail }\end{array}$ & 1 & $\begin{array}{l}\text { low intertidal to } \\
15 \mathrm{~m}\end{array}$ & $\begin{array}{l}\text { kelp stipe/holdfast, abundant in } \\
\text { surf grass (Phyllospadix) and } \\
\text { eelgrass (Zostera) habitat and in } \\
\text { shallow kelp forests }\end{array}$ & herbivore/detritivore \\
\hline Alia tuberosa & $\begin{array}{l}\text { Variegate dove } \\
\text { snail }\end{array}$ & 1 & sublittoral zone & $\begin{array}{l}\text { Kelp and eelgrass (Zostera), drift } \\
\text { algae, sand and gravel under kelp }\end{array}$ & epifaunal predator \\
\hline Amphissa spp. & $\begin{array}{l}\text { Dove shells, } \\
\text { Dove snails }\end{array}$ & 4 & $\begin{array}{l}\text { low intertidal and } \\
\text { subtidal }\end{array}$ & grazer on rocks & herbivore \\
\hline $\begin{array}{l}\text { Amphissa } \\
\text { versicolor }\end{array}$ & $\begin{array}{l}\text { Variegate } \\
\text { Amphissa, }\end{array}$ & 4 & intertidal to $46 \mathrm{~m}$ & rocky intertidal & carnivore \\
\hline $\begin{array}{l}\text { Callianax } \\
\text { biplicata }\end{array}$ & $\begin{array}{l}\text { Purple olive } \\
\text { shell }\end{array}$ & 2 & $\begin{array}{l}\text { low intertidal to } \\
50 \mathrm{~m}\end{array}$ & sandy bottoms/beaches & $\begin{array}{c}\text { omnivore/detritivore } \\
\text { Kelp blades and } \\
\text { detritus }\end{array}$ \\
\hline $\begin{array}{c}\text { Calliostoma } \\
\text { canaliculatum }\end{array}$ & $\begin{array}{c}\text { Channeled } \\
\text { topsnail }\end{array}$ & 1 & $\begin{array}{l}\text { low intertidal to } \\
37 \mathrm{~m}\end{array}$ & $\begin{array}{c}\text { lives on kelp (Macrocystis and } \\
\text { Cystoseira) }\end{array}$ & $\begin{array}{l}\text { herbivore/omnivore - } \\
\text { kelp, diatoms, } \\
\text { bryozoans, hydroids, } \\
\text { detritus }\end{array}$ \\
\hline $\begin{array}{l}\text { Calliostoma } \\
\text { ligatum }\end{array}$ & Blue topsnail & 1 & $\begin{array}{l}\text { low intertidal to } \\
54 \mathrm{~m}\end{array}$ & $\begin{array}{l}\text { found in and around kelp beds (on } \\
\text { Macrocystis and Cystoseira) and } \\
\text { eelgrass (Zostera) }\end{array}$ & $\begin{array}{l}\text { herbivore/omnivore - } \\
\text { kelp, diatoms, } \\
\text { bryozoans, hydroids, } \\
\text { tunicates, detritus }\end{array}$ \\
\hline Calliostoma spp. & Top snails & 1 & $\begin{array}{c}\text { low intertidal to } \\
\text { sublittoral }\end{array}$ & $\begin{array}{c}\text { species specific to kelps, some } \\
\text { species specific to portions of } \\
\text { stipe/blades/holdfasts }\end{array}$ & $\begin{array}{l}\text { herbivore/omnivore - } \\
\text { kelp, diatoms, } \\
\text { bryozoans, hydroids, } \\
\text { detritus }\end{array}$ \\
\hline $\begin{array}{c}\text { Cerithiopsis } \\
\text { carpenteri }\end{array}$ & $\begin{array}{c}\text { Carpenter's } \\
\text { miniature cerith }\end{array}$ & 4 & subtidal to $30 \mathrm{~m}$ & $\begin{array}{l}\text { common under rocks at low tide } \\
\text { and in sublittoral }\end{array}$ & $\begin{array}{l}\text { omnivore: primarily } \\
\text { sponges }\end{array}$ \\
\hline $\begin{array}{l}\text { Clathurella } \\
\text { canfieldi }\end{array}$ & - & 1,2 & intertidal & $\begin{array}{c}\text { in sand among surfgrass/eelgrass } \\
\text { roots }\end{array}$ & $\begin{array}{l}\text { predator - polychaete } \\
\text { worms }\end{array}$ \\
\hline $\begin{array}{l}\text { Conus } \\
\text { californicus }\end{array}$ & California cone & 2,4 & $\begin{array}{c}\text { low intertidal to } \\
\text { subtidal }\end{array}$ & rock crevices, sand pockets & $\begin{array}{c}\text { predator - worms, } \\
\text { mollusks, crustaceans, } \\
\text { buried in sand when } \\
\text { not eating }\end{array}$ \\
\hline $\begin{array}{c}\text { Crepidula } \\
\text { aculeata }\end{array}$ & $\begin{array}{l}\text { Spiny slipper } \\
\text { snail }\end{array}$ & 4 & $\begin{array}{c}\text { low intertidal to } 60 \\
\mathrm{~m}\end{array}$ & $\begin{array}{l}\text { common on rocks and hard debris } \\
\text { in shallow subtidal }\end{array}$ & $\begin{array}{c}\text { ciliary feeder on } \\
\text { detritus }\end{array}$ \\
\hline Crepidula coei & 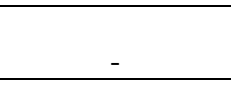 & 3,4 & intertidal & $\begin{array}{c}\text { common on gastropods - } \\
\text { Polinices (moon snails) } \\
\end{array}$ & $\begin{array}{c}\text { ciliary feeder on } \\
\text { detritus }\end{array}$ \\
\hline Crepidula & Northern white & 4 & 41 intertidal to & attaches to rocks or dead shells & ciliary feeder on \\
\hline
\end{tabular}




\begin{tabular}{|c|c|c|c|c|c|}
\hline nummaria & slipper snail & & subtidal & & detritus \\
\hline Crepidula onyx & $\begin{array}{l}\text { Onyx slipper } \\
\text { snail }\end{array}$ & 4 & intertidal to $90 \mathrm{~m}$ & $\begin{array}{c}\text { smaller males often stack on top } \\
\text { of larger females }\end{array}$ & $\begin{array}{c}\text { ciliary feeder on } \\
\text { detritus }\end{array}$ \\
\hline $\begin{array}{l}\text { Crepidula } \\
\text { perforans }\end{array}$ & $\begin{array}{l}\text { Western white } \\
\text { slipper snail }\end{array}$ & 4 & intertidal & $\begin{array}{l}\text { under rocks, resides on interiors } \\
\text { of dead shells }\end{array}$ & $\begin{array}{c}\text { ciliary feeder on } \\
\text { detritus }\end{array}$ \\
\hline Crepidula spp. & Slipper snails & 4 & $\begin{array}{l}\text { intertidal to } \\
\text { subtidal }\end{array}$ & & $\begin{array}{c}\text { ciliary feeder on } \\
\text { detritus }\end{array}$ \\
\hline $\begin{array}{c}\text { Crepipatella } \\
\text { lingulata }\end{array}$ & $\begin{array}{l}\text { Wrinkled slipper } \\
\text { snails }\end{array}$ & 4 & intertidal to $100 \mathrm{~m}$ & on rocks/snail shells & $\begin{array}{c}\text { ciliary feeder on } \\
\text { detritus }\end{array}$ \\
\hline Diodora arnoldi & $\begin{array}{c}\text { Neat-rib keyhole } \\
\text { limpet }\end{array}$ & 4 & $\begin{array}{c}\text { low intertidal to } \\
25 \mathrm{~m}\end{array}$ & undersides of rocks & herbivore \\
\hline Diodora aspera & $\begin{array}{l}\text { Rough keyhole } \\
\text { limpet }\end{array}$ & 4 & $\begin{array}{l}\text { low intertidal to } \\
\text { subtidal }\end{array}$ & undersides of rocks & $\begin{array}{c}\text { omnivore - prefers } \\
\text { encrusting bryozoans } \\
\text { but will eat algae }\end{array}$ \\
\hline Diodora spp. & Keyhole limpets & 4 & $\begin{array}{l}\text { intertidal to } \\
\text { subtidal }\end{array}$ & undersides of rocks & omnivore \\
\hline $\begin{array}{l}\text { Epitonium } \\
\text { tinctum }\end{array}$ & $\begin{array}{c}\text { Tinted } \\
\text { wentletrap, } \\
\text { White } \\
\text { wentletrap }\end{array}$ & 3 & $\begin{array}{l}\text { low intertidal to } \\
\text { subtidal }\end{array}$ & $\begin{array}{c}\text { on sand, at base of sea } \\
\text { anemones/feeds on tips of } \\
\text { Anthopleura tentacles }\end{array}$ & $\begin{array}{c}\text { predator - eats tips of } \\
\text { Anthopleura }\end{array}$ \\
\hline $\begin{array}{l}\text { Fissurella } \\
\text { volcano }\end{array}$ & Volcano limpet & 4 & $\begin{array}{l}\text { intertidal, mostly } \\
\text { middle intertidal }\end{array}$ & undersides of rocks & herbivore \\
\hline Fissurellidae & $\begin{array}{c}\text { Keyhole } \\
\text { limpets, Slit } \\
\text { limpets }\end{array}$ & 4 & $\begin{array}{l}\text { intertidal to } \\
\text { subtidal }\end{array}$ & on and under rocks and boulders & $\begin{array}{l}\text { omnivore - feed on } \\
\text { algae and detritus; } \\
\text { some are carnivores } \\
\text { and feed on sponges }\end{array}$ \\
\hline Fusinus kobelti & $\begin{array}{c}\begin{array}{c}\text { Kobelt's spindle- } \\
\text { shell }\end{array} \\
\end{array}$ & 2 & intertidal & sandy bottoms & $\begin{array}{c}\text { carnivorous } \\
\text { scavengers }\end{array}$ \\
\hline $\begin{array}{l}\text { Fusinus } \\
\text { luteopictus }\end{array}$ & $\begin{array}{l}\text { Painted spindle- } \\
\text { shell }\end{array}$ & 2 & $\begin{array}{c}\text { low intertidal to } \\
40 \mathrm{~m}\end{array}$ & rocks & $\begin{array}{l}\text { carnivorous } \\
\text { scavengers }\end{array}$ \\
\hline Garnotia adunca & $\begin{array}{l}\text { Hooked slipper- } \\
\text { shell }\end{array}$ & 3 & $\begin{array}{l}\text { mid to low } \\
\text { intertidal }\end{array}$ & $\begin{array}{c}\text { on intertidal snail shells including } \\
\text { Calliostoma, Chlorostoma, } \\
\text { Lirabuccinum }\end{array}$ & $\begin{array}{c}\text { ciliary feeder on } \\
\text { detritus }\end{array}$ \\
\hline $\begin{array}{c}\text { Garnotia } \\
\text { norrisiarum }\end{array}$ & $\begin{array}{l}\text { Norris slipper } \\
\text { shell }\end{array}$ & 3 & subtidal & $\begin{array}{l}\text { commonly and primarily on } \\
\text { Norrisia norrisi (and sometimes } \\
\text { Promartynia pulligo shells) }\end{array}$ & $\begin{array}{c}\text { ciliary feeder on } \\
\text { detritus }\end{array}$ \\
\hline Garnotia spp. & Slipper shells & 3 & & $\begin{array}{c}\text { attach to species specific host } \\
\text { shells }\end{array}$ & $\begin{array}{c}\text { ciliary feeder on } \\
\text { detritus }\end{array}$ \\
\hline $\begin{array}{c}\text { Hipponix } \\
\text { panamensis }\end{array}$ & Flat hoofsnail & 4 & intertidal to $46 \mathrm{~m}$ & clings to rocks, algae & $\begin{array}{l}\text { sedentary limpet, } \\
\text { obtain food with } \\
\text { extensible snout }\end{array}$ \\
\hline Hipponix tumens & $\begin{array}{c}\text { Ribbed } \\
\text { hoofsnail }\end{array}$ & 4 & low intertidal & rock crevices & $\begin{array}{l}\text { sedentary limpet, } \\
\text { obtain food with } \\
\text { extensible snout }\end{array}$ \\
\hline $\begin{array}{l}\text { Homalopoma } \\
\text { baculum }\end{array}$ & $\begin{array}{l}\text { Berry dwarf } \\
\text { turban }\end{array}$ & 4 & mid intertidal & under rocks & epifaunal predator \\
\hline $\begin{array}{l}\text { Homalopoma } \\
\quad \text { luridum }\end{array}$ & $\begin{array}{l}\text { Dall's dwarf } \\
\text { turban }\end{array}$ & 4 & $\begin{array}{l}\text { intertidal to } \\
\text { sublittoral }\end{array}$ & $\begin{array}{l}\text { rocks (note: shells are often used } \\
\text { by hermit crabs) }\end{array}$ & epifaunal predator \\
\hline Homalopoma spp. & Dwarf turbans & 4 & $\begin{array}{l}\text { intertidal to } \\
\text { sublittoral }\end{array}$ & rocks & epifaunal predator \\
\hline $\begin{array}{l}\text { Lacuna } \\
\text { marmorata }\end{array}$ & Chink shell & 1,4 & $\begin{array}{l}\text { mid to high } \\
\text { intertidal }\end{array}$ & $\begin{array}{l}\text { rocks, seaweed and seagrasses } \\
\text { (Phyllospadix and Zostera) }\end{array}$ & $\begin{array}{l}\text { herbivore - algae -- } \\
\text { is eaten by } \\
\text { Leptasterias }\end{array}$ \\
\hline Lacuna spp. & Chink shell & 1 & $\begin{array}{l}\text { mid to high } \\
\text { intertidal }\end{array}$ & $\begin{array}{c}\text { species specific to kelps and sea } \\
\text { grasses in moderately shallow } \\
\text { water }\end{array}$ & herbivore \\
\hline
\end{tabular}




\begin{tabular}{|c|c|c|c|c|c|}
\hline Lirularia spp. & Minute trochids & 1,2 & $\begin{array}{c}\text { intertidal to } \\
\text { sublittoral but } \\
\text { mostly sublittoral }\end{array}$ & $\begin{array}{c}\text { on gravel/loose rocks/algae, } \\
\text { common at the base of kelp and } \\
\text { on eelgrass (Zostera) }\end{array}$ & herbivore \\
\hline Littorina keenae & Flat periwinkle & 4 & In the splash zone & rocks in the high tide line & $\begin{array}{l}\text { herbivore: diatoms, } \\
\text { films }\end{array}$ \\
\hline Littorina plena & $\begin{array}{c}\text { Black } \\
\text { periwinkle }\end{array}$ & 4 & high intertidal zone & $\begin{array}{l}\text { rocks with algae, mussels and } \\
\text { barnacles }\end{array}$ & herbivore \\
\hline $\begin{array}{l}\text { Littorina } \\
\text { scutulata }\end{array}$ & $\begin{array}{l}\text { Checkered } \\
\text { periwinkle }\end{array}$ & 4 & $\begin{array}{l}\text { common in upper } \\
\text { intertidal zone, } \\
\text { lower than L. } \\
\text { planaxis }\end{array}$ & rocks & $\begin{array}{l}\text { herbivore: diatoms, } \\
\text { microscopic algae, } \\
\text { lichens as well as } \\
\text { macroalgae }\end{array}$ \\
\hline Littorina spp. & Periwinkles & 4 & $\begin{array}{l}\text { upper and high } \\
\text { intertidal }\end{array}$ & $\begin{array}{l}\text { on rocks in shallow water along } \\
\text { shoreline }\end{array}$ & herbivore \\
\hline Lottia asmi & Black limpet & 3 & $\begin{array}{l}\text { mid to low } \\
\text { intertidal }\end{array}$ & $\begin{array}{l}\text { attaches to host shell or rock, can } \\
\text { move from one to another, found } \\
\text { on Chlorostoma funebralis } \\
\text { (primarily) or C. gallina, but also } \\
\text { Mytilus and rocks }\end{array}$ & $\begin{array}{c}\text { herbivore: microscopic } \\
\text { algae on host } \\
\text { shell/rocks }\end{array}$ \\
\hline Lottia digitalis & $\begin{array}{l}\text { Ribbed limpet, } \\
\text { Fingered limpet }\end{array}$ & 4 & $\begin{array}{l}\text { upper intertidal } \\
\text { and splash zone }\end{array}$ & $\begin{array}{c}\text { vertical or overhanging rock } \\
\text { faces, exposed rocky coasts, } \\
\text { occasionally on gooseneck } \\
\text { barnacles (these have lighter } \\
\text { morph) }\end{array}$ & $\begin{array}{c}\text { microscopic algae and } \\
\text { newly settled } \\
\text { barnacles }\end{array}$ \\
\hline Lottia fenestrata & $\begin{array}{l}\text { Fenestrate } \\
\text { limpet, } \\
\text { Chocolate } \\
\text { limpet }\end{array}$ & 4 & $\begin{array}{l}\text { mid to low } \\
\text { intertidal }\end{array}$ & $\begin{array}{l}\text { reef rocks and boulders adjacent } \\
\text { to loose sand }\end{array}$ & herbivore \\
\hline Lottia insessa & Seaweed limpet & 1 & low intertidal & $\begin{array}{c}\text { common on stipes and holdfasts } \\
\text { of } \\
\text { Egregia (feather boa kelp) }\end{array}$ & $\begin{array}{l}\text { herbivore: feed } \\
\text { directly on the kelp, } \\
\text { forming scars and } \\
\text { eventually destroying } \\
\text { it }\end{array}$ \\
\hline Lottia instabilis & $\begin{array}{c}\text { Unstable } \\
\text { seaweed limpet }\end{array}$ & 1 & $\begin{array}{l}\text { low intertidal, } \\
\text { subtidal }\end{array}$ & $\begin{array}{c}\text { kelp stipes (primarily Laminaria } \\
\text { setchelli and Pterygophora } \\
\text { californica) }\end{array}$ & $\begin{array}{l}\text { herbivore: kelp stipes } \\
\text { and other algae }\end{array}$ \\
\hline Lottia ochracea & Yellow limpet & 1,4 & $\begin{array}{l}\text { one of few limpet } \\
\text { species in } \\
\text { sublittoral zone }\end{array}$ & $\begin{array}{l}\text { in sublittoral depths under kelp } \\
\text { and surfgrass (Phyllospadix) and } \\
\text { the undersides of small rocks at } \\
\text { low tide }\end{array}$ & $\begin{array}{l}\text { herbivore: kelp stipes } \\
\text { and other algae }\end{array}$ \\
\hline Lottia palacea & Surfgrass limpet & 1 & low intertidal & $\begin{array}{l}\text { common on blades of surfgrass } \\
\text { (Phyllospadix) along open coast, } \\
\text { occasionally on eelgrass }\end{array}$ & $\begin{array}{l}\text { herbivore: feeds on } \\
\text { superficial algae }\end{array}$ \\
\hline $\begin{array}{c}\text { Lottia } \\
\text { paradigitalis }\end{array}$ & - & 3,4 & $\begin{array}{l}\text { high and mid } \\
\text { intertidal }\end{array}$ & $\begin{array}{c}\text { rocks, shells of turban snails and } \\
\text { mussel (Mytilus) }\end{array}$ & herbivore \\
\hline $\begin{array}{l}\text { Lottia pelta (rock } \\
\text { morph) }\end{array}$ & Shield limpet & 4 & $\begin{array}{c}\text { mid to low } \\
\text { intertidal }\end{array}$ & rocky reef, rocks and boulders & herbivore \\
\hline $\begin{array}{c}\text { Lottia pelta (dark } \\
\text { seaweed } \\
\text { morphology) }\end{array}$ & Shield limpet & 1 & $\begin{array}{l}\text { mid to low } \\
\text { intertidal }\end{array}$ & $\begin{array}{l}\text { stipes and holdfasts of kelps } \\
\text { (Egregia and others) }\end{array}$ & herbivore: kelps \\
\hline Lottia persona & $\begin{array}{l}\text { Masked limpet, } \\
\text { Speckled limpet }\end{array}$ & 4 & $\begin{array}{c}\text { high to mid } \\
\text { intertidal }\end{array}$ & rocks & herbivore \\
\hline Lottia rosacea & Rose limpet & 2,3 & $\begin{array}{l}\text { common in } \\
\text { subtidal }\end{array}$ & associated with coralline algae & herbivore \\
\hline Lottia scabra & Rough limpet & 4,3 & mid intertidal & $\begin{array}{c}\text { rocky reefs and boulders, often } \\
\text { found on Owl limpet ( } L . \\
\text { gigantea) }\end{array}$ & herbivore: algal films \\
\hline
\end{tabular}




\begin{tabular}{|c|c|c|c|c|c|}
\hline Lottia scutum & $\begin{array}{l}\text { Pacific plate } \\
\text { limpet }\end{array}$ & 4 & $\begin{array}{c}\text { mid to low } \\
\text { intertidal }\end{array}$ & rocks & $\begin{array}{l}\text { herbivore: algal films, } \\
\text { crustose algae }\end{array}$ \\
\hline Lottia strigatella & $\begin{array}{c}\text { Checkered } \\
\text { limpet }\end{array}$ & 1,4 & $\begin{array}{l}\text { middle intertidal to } \\
\text { sublittoral under } \\
\text { kelp }\end{array}$ & $\begin{array}{c}\text { kelp beds, eelgrass (Zostera) } \\
\text { roots, algae }\end{array}$ & $\begin{array}{l}\text { herbivore: microscopic } \\
\text { algae and diatoms }\end{array}$ \\
\hline $\begin{array}{c}\text { Lucapinella } \\
\text { callomarginata }\end{array}$ & $\begin{array}{l}\text { Hard-edged } \\
\text { fleshy limpet }\end{array}$ & 4 & $\begin{array}{l}\text { low intertidal to } \\
\text { subtidal }\end{array}$ & underside of rocks & $\begin{array}{c}\text { omnivore: primarily } \\
\text { sponges (Tetilla), but } \\
\text { will consume algal } \\
\text { films }\end{array}$ \\
\hline $\begin{array}{l}\text { Mitromorpha } \\
\text { aspera }\end{array}$ & $\begin{array}{l}\text { Rough miter- } \\
\text { form } \\
\end{array}$ & 2 & intertidal & $\begin{array}{l}\text { gravel at low tide and in } \\
\text { sublittoral }\end{array}$ & epifaunal predator \\
\hline $\begin{array}{c}\text { Nucella } \\
\text { emarginata }\end{array}$ & $\begin{array}{l}\text { Emarginate dog } \\
\text { winkle }\end{array}$ & 3,4 & middle intertidal & $\begin{array}{c}\text { rocks, mussel beds, often in } \\
\text { association with } \\
\text { O. circumtexta } \\
\end{array}$ & $\begin{array}{l}\text { predator: prey on } \\
\text { Mytilus, barnacles } \\
\text { (Balanus }) \\
\end{array}$ \\
\hline Nucella spp. & Dogwinkle & 4 & shallow intertidal & rocks & predator \\
\hline $\begin{array}{l}\text { Ocinebrina } \\
\text { (Ocenebra) } \\
\text { circumtexta }\end{array}$ & $\begin{array}{c}\text { Circled rock } \\
\text { shell }\end{array}$ & 3,4 & $\begin{array}{l}\text { intertidal, common } \\
\text { in rocky crevices } \\
\text { at midtide } \\
\end{array}$ & $\begin{array}{c}\text { rocks in heavy surf areas, often } \\
\text { associated with barnacles } \\
\text { (Balanus) }\end{array}$ & predator \\
\hline $\begin{array}{c}\text { Ocinebrina } \\
\text { (Ocenebra) } \\
\text { interfossa }\end{array}$ & $\begin{array}{c}\text { Sculptured rock } \\
\text { shell }\end{array}$ & 4 & intertidal to $100 \mathrm{~m}$ & under rocks & $\begin{array}{c}\text { predator, can drill into } \\
\text { mollusks and } \\
\text { barnacles }\end{array}$ \\
\hline $\begin{array}{c}\text { Ocinebrina } \\
\text { (Ocenebra) lurida }\end{array}$ & Lurid rock shell & 4 & $\begin{array}{l}\text { intertidal to } 200 \mathrm{~m}, \\
\text { common at low } \\
\text { tide }\end{array}$ & $\begin{array}{l}\text { on/under rocks, common in low } \\
\text { intertidal in northern CA, rare in } \\
\text { sublittoral in southern CA }\end{array}$ & $\begin{array}{c}\text { predator, eats } \\
\text { Cryptochiton stelleri } \\
\text { and Mytilus } \\
\end{array}$ \\
\hline $\begin{array}{c}\text { Ocinebrina } \\
\text { (Ocenebra) minor }\end{array}$ & Minor rock shell & 1,2 & sublittoral zone & $\begin{array}{l}\text { not uncommon in sublittoral zone, } \\
\text { particularly under kelp }\end{array}$ & predator \\
\hline $\begin{array}{c}\text { Ocinebrina } \\
\text { (Ocenebra) spp. }\end{array}$ & Rock shell & 4 & $\begin{array}{c}\text { intertidal to } \\
\text { sublittoral }\end{array}$ & rocks and crevices, rocky bottoms & predator \\
\hline Odostomia nota & Odostome & 1 & $\begin{array}{l}\text { intertidal, shallow } \\
\text { water }\end{array}$ & $\begin{array}{c}\text { common on eelgrass (Zostera) } \\
\text { roots } \\
\end{array}$ & $\begin{array}{c}\text { may be parasitic on } \\
\text { certain molluscs }\end{array}$ \\
\hline $\begin{array}{c}\text { Pleisiocystiscus } \\
\text { jewettii }\end{array}$ & - & 1,2 & low intertidal & $\begin{array}{c}\text { gravel of tide pools, with coralline } \\
\text { algae, in surfgrass (Phyllospadix) } \\
\text { holdfasts }\end{array}$ & predatory snail \\
\hline $\begin{array}{l}\text { Pseudomelatoma } \\
\text { torosa }\end{array}$ & $\begin{array}{l}\text { Knobbed tower- } \\
\text { shell }\end{array}$ & 4 & $\begin{array}{l}\text { low intertidal to } \\
30 \mathrm{~m}\end{array}$ & rocky areas & $\begin{array}{l}\text { predatory snail - } \\
\text { polychaete worms }\end{array}$ \\
\hline $\begin{array}{c}\text { Stylidium } \\
\text { (Bittium) } \\
\text { eschrichtii } \\
\end{array}$ & Threaded cerith & 1,2 & $\begin{array}{c}\text { low intertidal and } \\
\text { sublittoral }\end{array}$ & $\begin{array}{l}\text { clean coarse sand among eelgrass } \\
(\text { Zostera)/rocks/coralline algae }\end{array}$ & $\begin{array}{l}\text { herbivore: } \\
\text { algae/detritus }\end{array}$ \\
\hline Terebra sp. & Auger shell & 2 & intertidal to $1000 \mathrm{~m}$ & offshore sandy bottoms & predator \\
\hline $\begin{array}{l}\text { Trimusculus } \\
\text { reticulatus }\end{array}$ & $\begin{array}{c}\text { Reticulate } \\
\text { gadinia }\end{array}$ & 4 & mid intertidal & rock overhangs & $\begin{array}{c}\text { planktivore; primarily } \\
\text { pelagic diatoms }\end{array}$ \\
\hline $\begin{array}{l}\text { Volvarina } \\
\text { taeniolata }\end{array}$ & $\begin{array}{l}\text { California } \\
\text { marginella }\end{array}$ & 4 & $\begin{array}{l}\text { intertidal and } \\
\text { sublittoral }\end{array}$ & rocks & predator \\
\hline
\end{tabular}


Table 5. CA-SMI-603, Unit 1, MNI of Small Gastropods.

\begin{tabular}{|c|c|c|c|c|c|c|c|c|}
\hline & & & Strat & & & & & \\
\hline Taxa & II & III & IV & $\mathbf{V}$ & VI & VII & Total & $\%$ \\
\hline Acanthinucella punctulata & - & - & - & 1 & - & - & 1 & 0.0 \\
\hline Acmaea mitra & 12 & 3 & 20 & 17 & 3 & 1 & 56 & 1.7 \\
\hline Alia carinata & 10 & 6 & 38 & 12 & 4 & 12 & 82 & 2.5 \\
\hline Alia tuberosa & 1 & - & 17 & 8 & - & 1 & 27 & 0.8 \\
\hline Amphissa spp. & - & - & - & - & - & 4 & 4 & 0.1 \\
\hline Amphissa versicolor & 19 & 2 & 21 & 15 & - & - & 57 & 1.7 \\
\hline Callianax biplicata & 2 & - & 1 & 1 & 1 & - & 5 & 0.1 \\
\hline Calliostoma spp. & 1 & - & - & 2 & - & - & 3 & 0.1 \\
\hline Clathurella canfieldi & 1 & 1 & - & - & - & - & 2 & 0.1 \\
\hline Conus californicus & - & - & 2 & - & - & 1 & 3 & 0.1 \\
\hline Crepidula coei & 9 & 1 & 3 & 6 & 12 & - & 31 & 0.9 \\
\hline Crepidula nummaria & - & - & - & - & - & 2 & 2 & 0.1 \\
\hline Crepidula perforans & 1 & - & - & 1 & - & - & 2 & 0.1 \\
\hline Crepipatella lingulata & - & 1 & - & - & - & - & 1 & 0.0 \\
\hline Diodora arnoldi & - & - & 1 & - & - & - & 1 & 0.0 \\
\hline Diodora aspera & - & - & 2 & - & - & - & 2 & 0.1 \\
\hline Diodora spp. & - & 1 & - & - & - & - & 1 & 0.0 \\
\hline Epitonum tinctum & - & - & 1 & 1 & - & - & 2 & 0.1 \\
\hline Fissurella volcano & 22 & 3 & 28 & 29 & 6 & 10 & 98 & 3.0 \\
\hline Garnotia adunca & 57 & 5 & 11 & 175 & 166 & 16 & 430 & 13.0 \\
\hline Garnotia norrisiarum & 6 & - & 10 & 3 & 12 & 7 & 38 & 1.1 \\
\hline Garnotia spp. & - & - & - & 1 & 6 & 2 & 9 & 0.3 \\
\hline Hipponix panamensis & 1 & - & 3 & - & - & 2 & 6 & 0.2 \\
\hline Hipponix tumens & 1 & - & 2 & 1 & 1 & - & 5 & 0.2 \\
\hline Homalopoma baculum & - & - & 1 & 10 & - & 1 & 12 & 0.4 \\
\hline Homalopoma luridum & 1 & 6 & 16 & 1 & - & 2 & 26 & 0.8 \\
\hline Lacuna marmorata & 10 & 1 & - & - & - & 1 & 12 & 0.4 \\
\hline Lacuna spp. & 1 & - & 1 & 10 & - & 1 & 13 & 0.4 \\
\hline Lirularia spp. & - & - & 8 & 1 & - & - & 9 & 0.3 \\
\hline Littorina keenae & 6 & 2 & 11 & 10 & 1 & 4 & 34 & 1.0 \\
\hline Littorina plena & 9 & 4 & 14 & 12 & - & - & 39 & 1.2 \\
\hline Littorina scutulata & - & - & - & 2 & - & - & 2 & 0.1 \\
\hline Littorina spp. & - & - & - & - & 1 & - & 1 & 0.0 \\
\hline Lottia asmi & 4 & 1 & 16 & 72 & 26 & 15 & 134 & 4.0 \\
\hline Lottia digitalis & 48 & 12 & 66 & 48 & 31 & 5 & 210 & 6.3 \\
\hline Lottia fenestrata & 11 & 6 & 40 & 22 & 17 & - & 96 & 2.9 \\
\hline Lottia insessa & 8 & - & 8 & 6 & 1 & 6 & 29 & 0.9 \\
\hline Lottia ochracea & 1 & 3 & 4 & 9 & 11 & 6 & 34 & 1.0 \\
\hline Lottia palacea & - & - & 2 & - & - & - & 2 & \\
\hline
\end{tabular}




\begin{tabular}{|c|c|c|c|c|c|c|c|c|}
\hline Lottia paradigitalis & - & 6 & 4 & 7 & 38 & 23 & 78 & 2.4 \\
\hline Lottia pelta (rock morph) & 21 & 14 & 60 & 69 & 14 & 28 & 206 & 6.3 \\
\hline Lottia pelta (seaweed morph) & 52 & 10 & 92 & 110 & 111 & 51 & 426 & 12.8 \\
\hline Lottia persona & 1 & 5 & 7 & 8 & 1 & - & 22 & 0.7 \\
\hline Lottia rosacea & - & - & - & - & - & 2 & 2 & 0.1 \\
\hline Lottia scabra & 79 & 28 & 156 & 192 & 88 & 47 & 590 & 17.8 \\
\hline Lottia scutum & 7 & 3 & 13 & 44 & - & 3 & 70 & 2.1 \\
\hline Lottia strigatella & 10 & 8 & 48 & 44 & 68 & 21 & 199 & 6.0 \\
\hline Lottia spp. & 49 & 1 & 19 & 30 & 11 & 19 & 129 & 4.0 \\
\hline Nucella emarginata & 2 & 1 & 3 & 4 & 1 & 2 & 13 & 0.4 \\
\hline Nucella spp. & - & 1 & - & 2 & - & 4 & 7 & 0.2 \\
\hline Ocinebrina circumtexta & 1 & 3 & - & 3 & 2 & - & 9 & 0.3 \\
\hline Ocinebrina interfossa & - & - & 1 & - & - & - & 1 & 0.0 \\
\hline Ocinebrina lurida & - & - & - & 1 & - & - & 1 & 0.0 \\
\hline Ocinebrina minor & - & - & - & 1 & - & - & 1 & 0.0 \\
\hline Ocinebrina spp. & 1 & - & 3 & 3 & - & 1 & 8 & 0.2 \\
\hline Odostomia nota & 1 & 1 & 2 & 3 & - & - & 7 & 0.2 \\
\hline Pleisiocystiscus jewettii & - & - & 1 & - & - & 1 & 2 & 0.1 \\
\hline Stylidium eschrichtii & - & - & 3 & - & - & - & 3 & 0.1 \\
\hline Terebra sp. & 1 & - & - & 3 & - & - & 4 & 0.1 \\
\hline Trimusculus reticulatus & - & - & - & 3 & - & 2 & 5 & 0.2 \\
\hline Volvarina taeniolata & - & - & - & 1 & - & - & 1 & 0.0 \\
\hline Total & 467 & 139 & 758 & 1003 & 632 & 303 & 3305 & 100 \\
\hline
\end{tabular}


Table 6. Quantitative Measures.

\begin{tabular}{|c|c|c|c|c|c|c|c|c|c|}
\hline $\begin{array}{c}\text { Site } \\
(\mathbf{C A}-) \\
\end{array}$ & Unit(s) & Strata & $\begin{array}{c}\text { Excavated } \\
\text { Volume } \\
\left(\mathbf{m}^{3}\right)\end{array}$ & $\begin{array}{c}\text { Taxa } \\
\text { Richness } \\
\end{array}$ & $\begin{array}{c}\text { Small } \\
\text { Gastropod } \\
\text { Density } \\
\left(\mathrm{MNI} / \mathbf{m}^{3}\right) \\
\end{array}$ & $\begin{array}{c}\text { Seaweed } \\
\text { and } \\
\text { Seagrass } \\
\text { Density } \\
\left(\mathrm{MNI} / \mathrm{m}^{3}\right)\end{array}$ & $\begin{array}{c}\text { Seaweed } \\
\text { and } \\
\text { Seagrass } \\
\% \text { MNI }\end{array}$ & $\begin{array}{c}\text { Diversity } \\
\left(\mathbf{H}^{\prime}\right)\end{array}$ & $\begin{array}{c}\text { Equitability } \\
\left(\mathbf{V}^{\prime}\right)\end{array}$ \\
\hline SNI-40 & 11,12 & IIHR & 0.138 & 30 & 2021.7 & 297.1 & 14.9 & 2.805 & 0.825 \\
\hline SNI-40 & 11,12 & IIB & 0.02 & 16 & 3000 & 500 & 16.7 & 2.382 & 0.86 \\
\hline SNI-40 & 11,12 & $\begin{array}{l}\text { Dark } \\
\text { Feat. }\end{array}$ & 0.016 & 14 & 4312.5 & 1562.5 & 36.1 & 2.343 & 0.865 \\
\hline SNI-40 & 11,12 & IIHC & 0.2765 & 35 & 3045.2 & 654.6 & 21.6 & 2.752 & 0.773 \\
\hline \multicolumn{3}{|c|}{ Totals: } & 0.4505 & 40 & 2772.5 & 572.7 & & & \\
\hline SMI-603 & 1 & II & 0.362 & 34 & 1284.5 & 265.2 & 20.7 & 2.768 & 0.778 \\
\hline SMI-603 & 1 & III & 0.14 & 28 & 992.9 & 214.3 & 21.6 & 2.894 & 0.869 \\
\hline SMI-603 & 1 & IV & 0.461 & 39 & 1644.3 & 485.9 & 29.5 & 2.897 & 0.792 \\
\hline SMI-603 & 1 & V & 0.208 & 44 & 4822.1 & 995.2 & 20.7 & 2.771 & 0.733 \\
\hline SMI-603 & 1 & VI & 0.127 & 23 & 4976.4 & 1535.4 & 30.9 & 2.318 & 0.738 \\
\hline SMI-603 & 1 & VII & 0.09 & 32 & 3366.7 & 1111.1 & 32.9 & 2.818 & 0.812 \\
\hline \multicolumn{3}{|c|}{ Totals: } & 1.388 & 59 & 2377.5 & 612.4 & & & \\
\hline
\end{tabular}


Table 7. CA-SNI-40, Units 11 and 12A, MNI of Small Gastropods

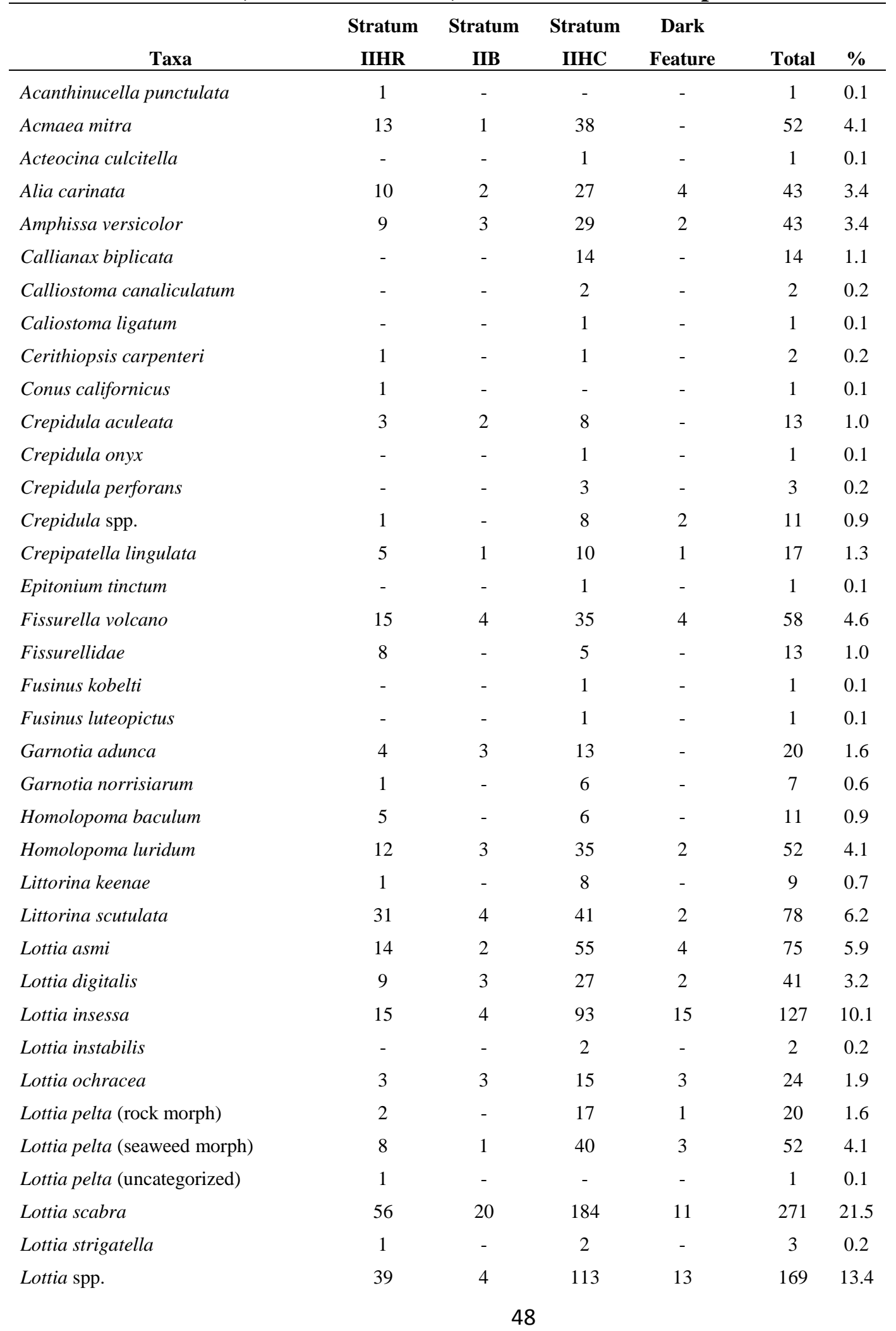




\begin{tabular}{lcccccc} 
Lucapinella callomarginata & 1 & - & - & - & 1 & 0.1 \\
Mitromorpha aspera & 1 & - & - & - & 1 & 0.1 \\
Ocinebrina circumtexta & 1 & - & 5 & - & 6 & 0.5 \\
Pseudomelatoma torosa & - & - & 1 & - & 1 & 0.1 \\
Stylidium eschrichtii & 3 & - & - & - & 3 & 0.2 \\
Trimusculatus reticulatus & 4 & - & 6 & - & 10 & 0.8 \\
\hline Total & 278 & 60 & 855 & 69 & 1263 & 100 \\
\hline
\end{tabular}




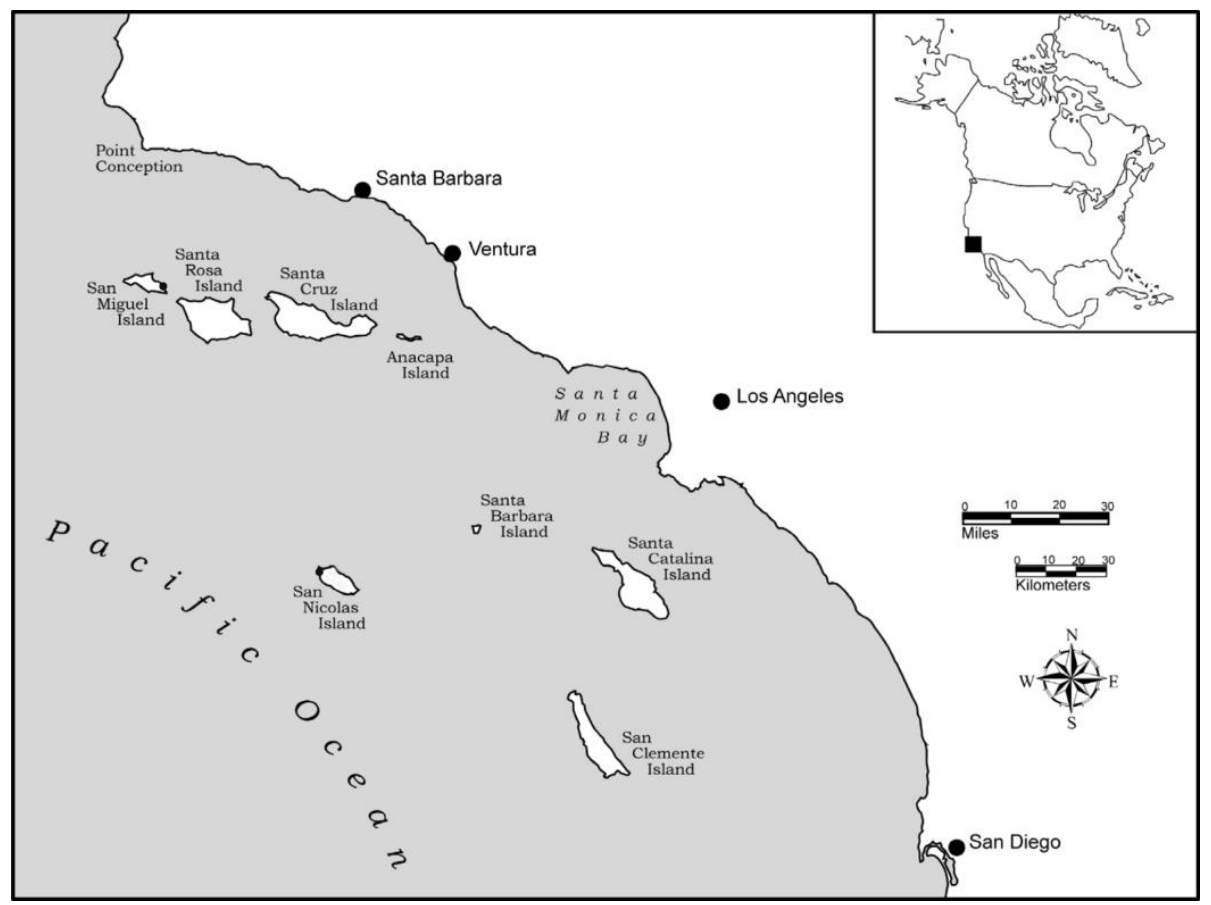

Figure 1. Map of the California Channel Islands with CA-SMI-603 demarcated on the northeast coast of San Miguel Island and CA-SNI-40 demarcated on the west end of San Nicolas Island. 


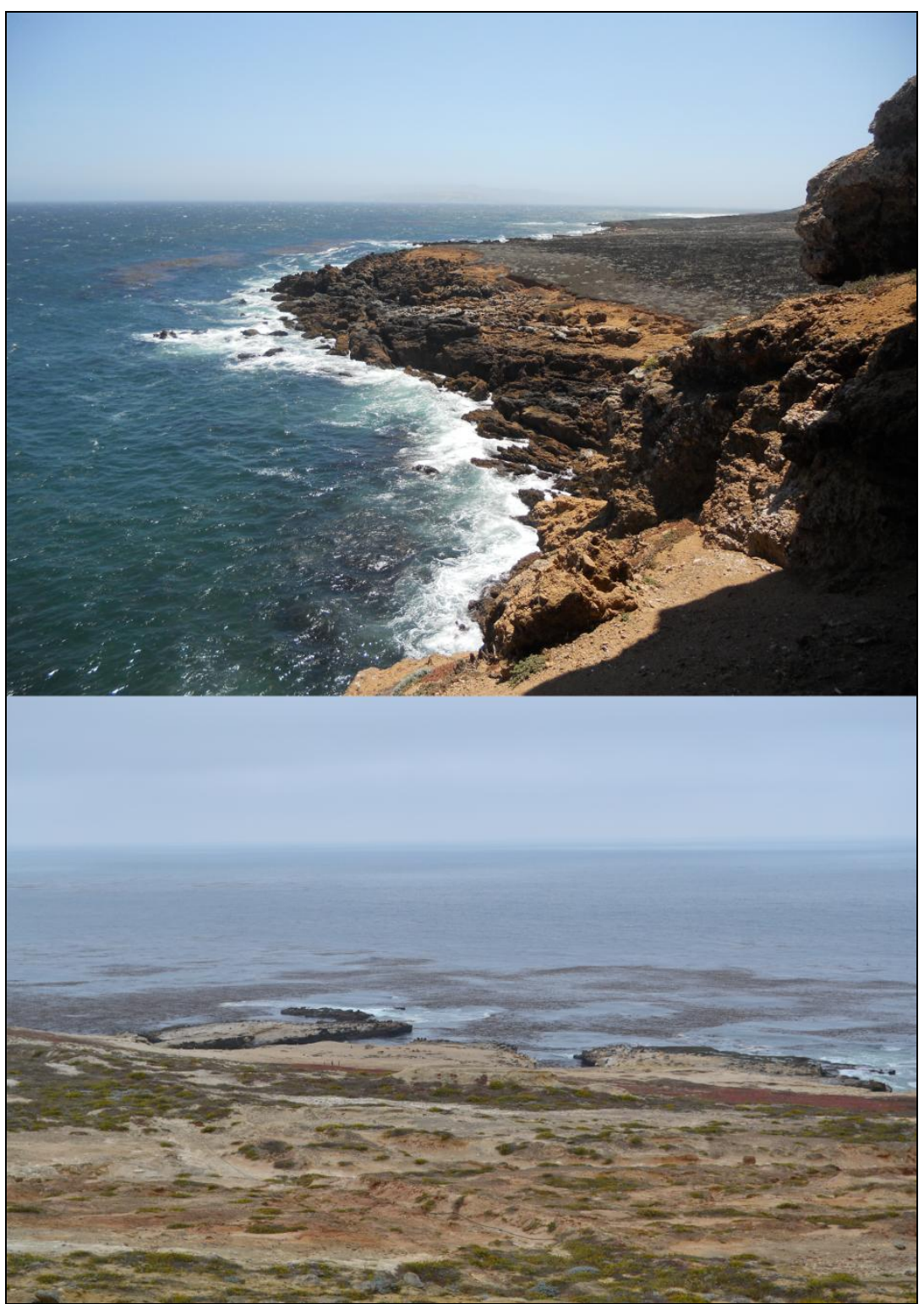

Figure 4. View of rocky shore and kelp patches looking out from Cave of the Chimneys (CA-SMI-603, above) and CA-SNI-40 (below). 


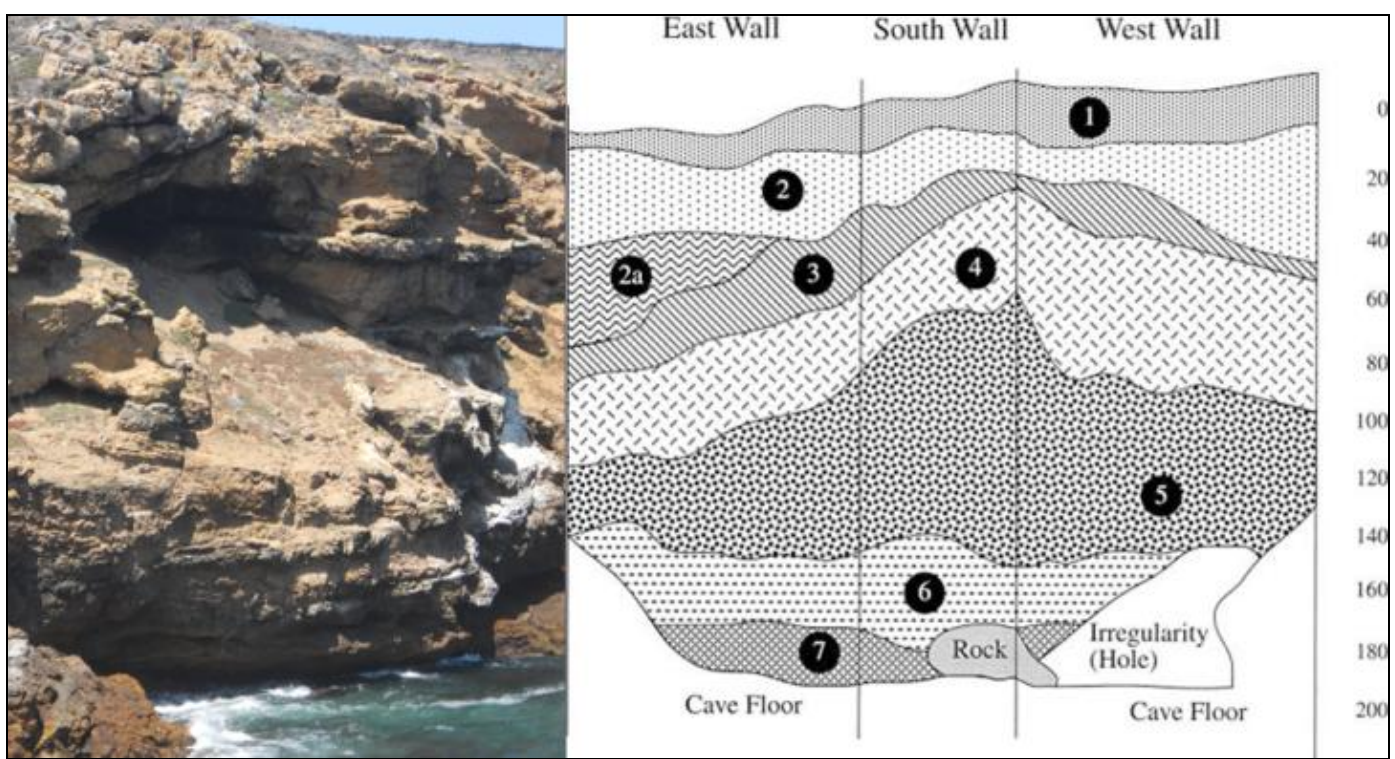

Figure 5. Entrance to Cave of the Chimneys (CA-SMI-603) and stratigraphic profile drawing of Unit 1.

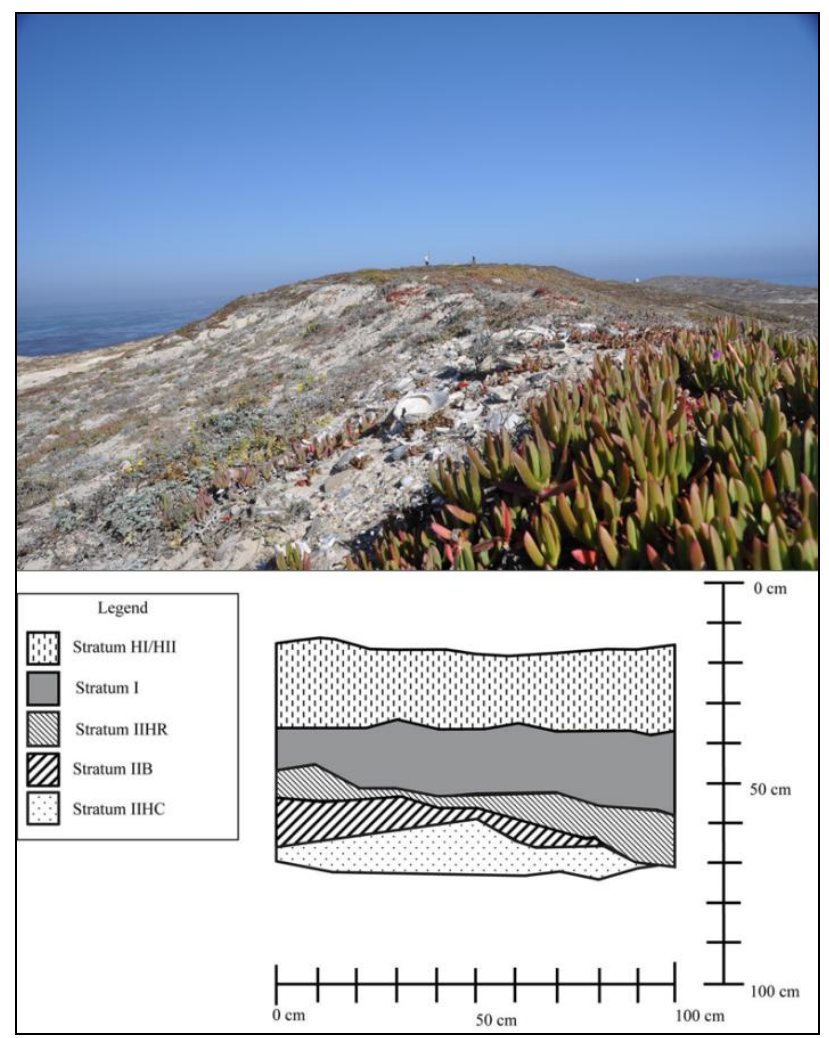

Figure 6. The large dune that comprises CA-SNI-40 (facing west) and stratigraphic profile drawing of Unit 12A. 


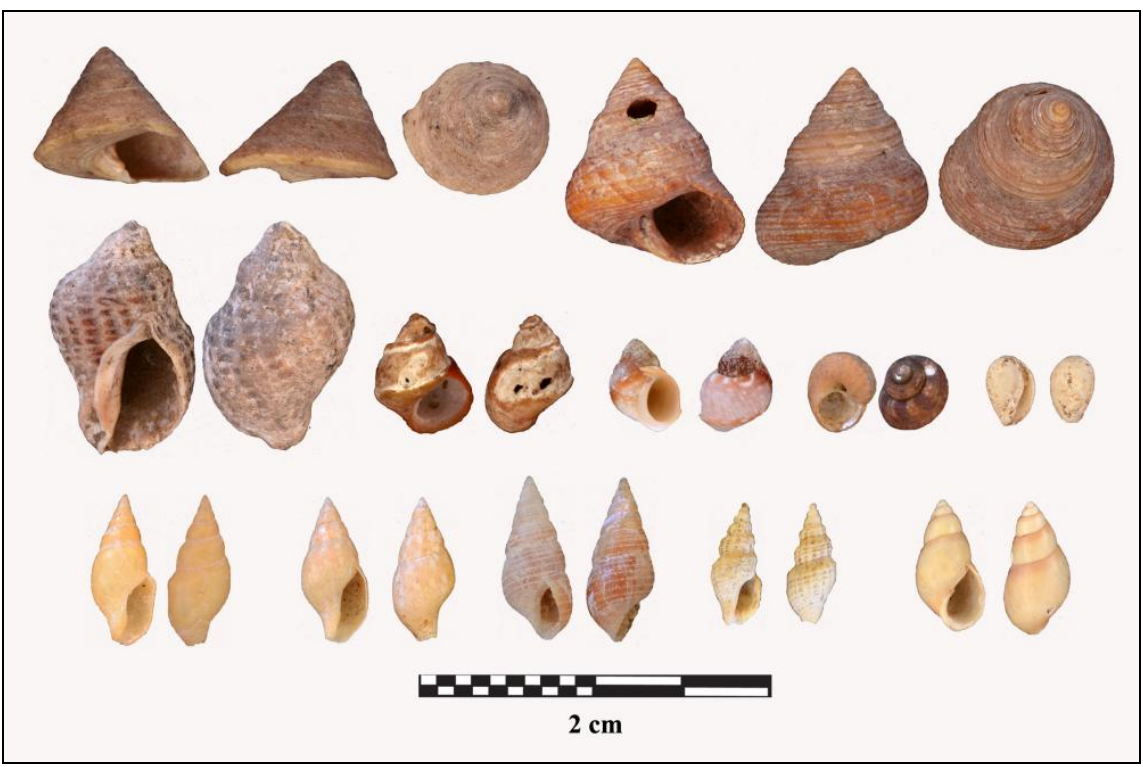

Figure 2. Archaeological examples of seaweed associates identified in this study (top left to bottom right): Callisotoma canaliculatum, Calliostoma ligatum, Acanthinucella punctulata, Lacuna marmorata, Lacuna unifasciata, Lirularia sp., Pleisiocystiscus jewettii, Alia carinata, Alia tuberosa, Stylidium eschrichtii, Clathurella canfieldi, and Odostomia nota. 


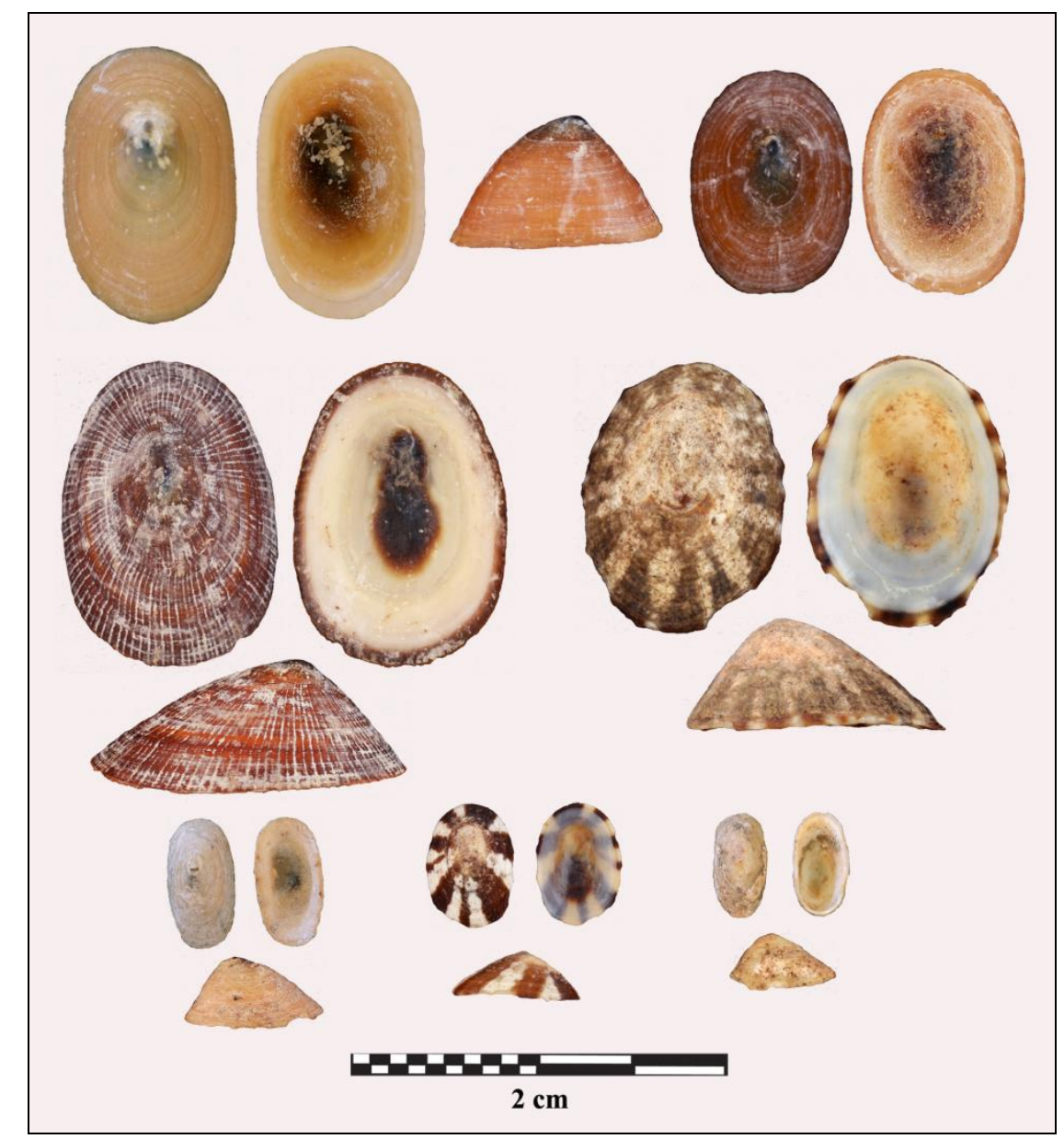

Figure 3. Archaeological examples of seaweed and seagrass limpets identified in this study (top left to bottom right): light and dark morphologies of Lottia insessa, L. pelta (seaweed morphology), L. strigatella. L. instabilis, $L$. ochracea, and L. palacea. 
Relative Abundance of CA-SMI-603 Taxa

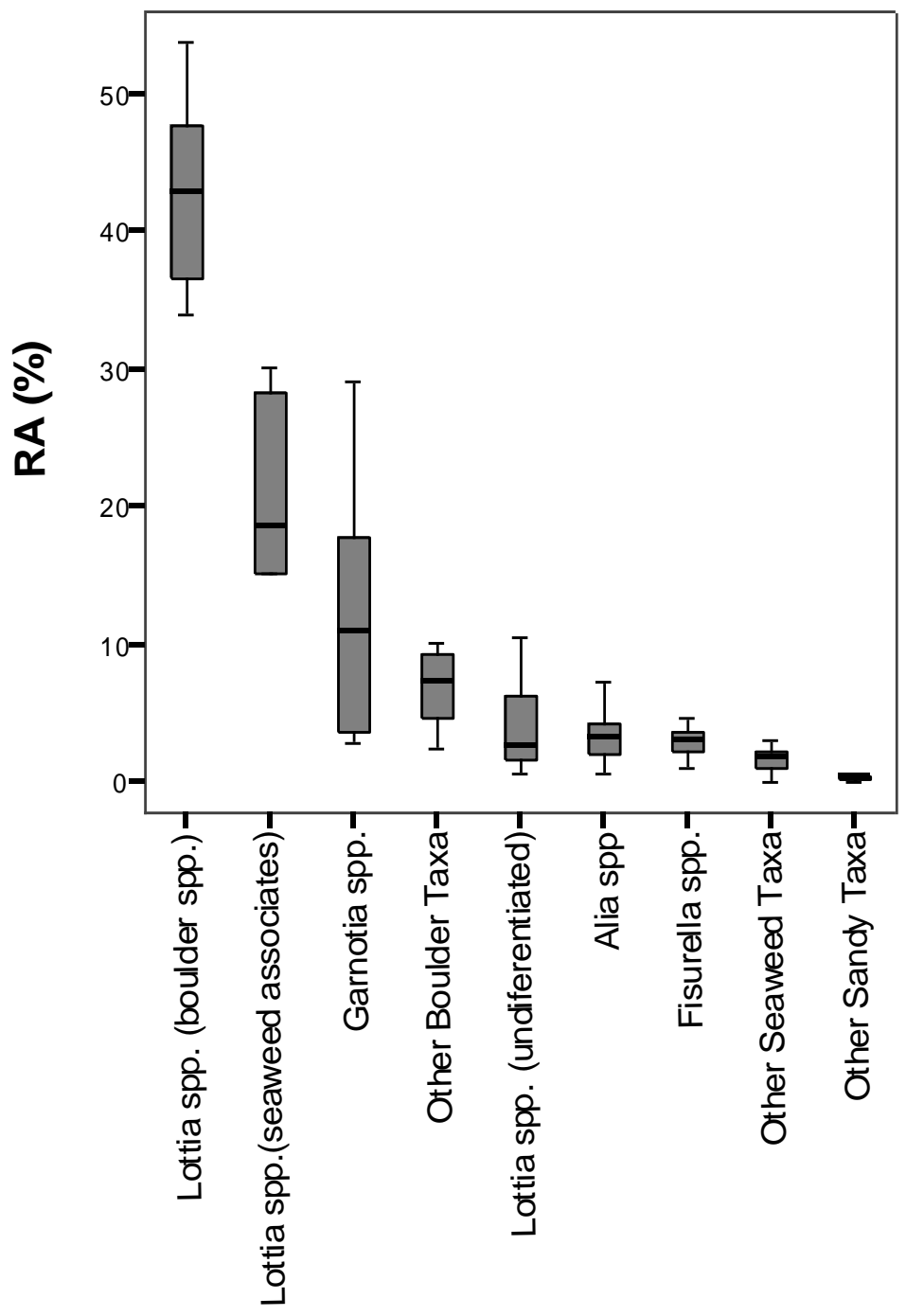

Taxa

Figure 7. Composition of small gastropod taxa from CA-SMI-603. Boxplots include mean relative abundance and interquartile ranges. Error bars denote full ranges. $N=$ number of analyzed strata (6), RA = relative abundance. 


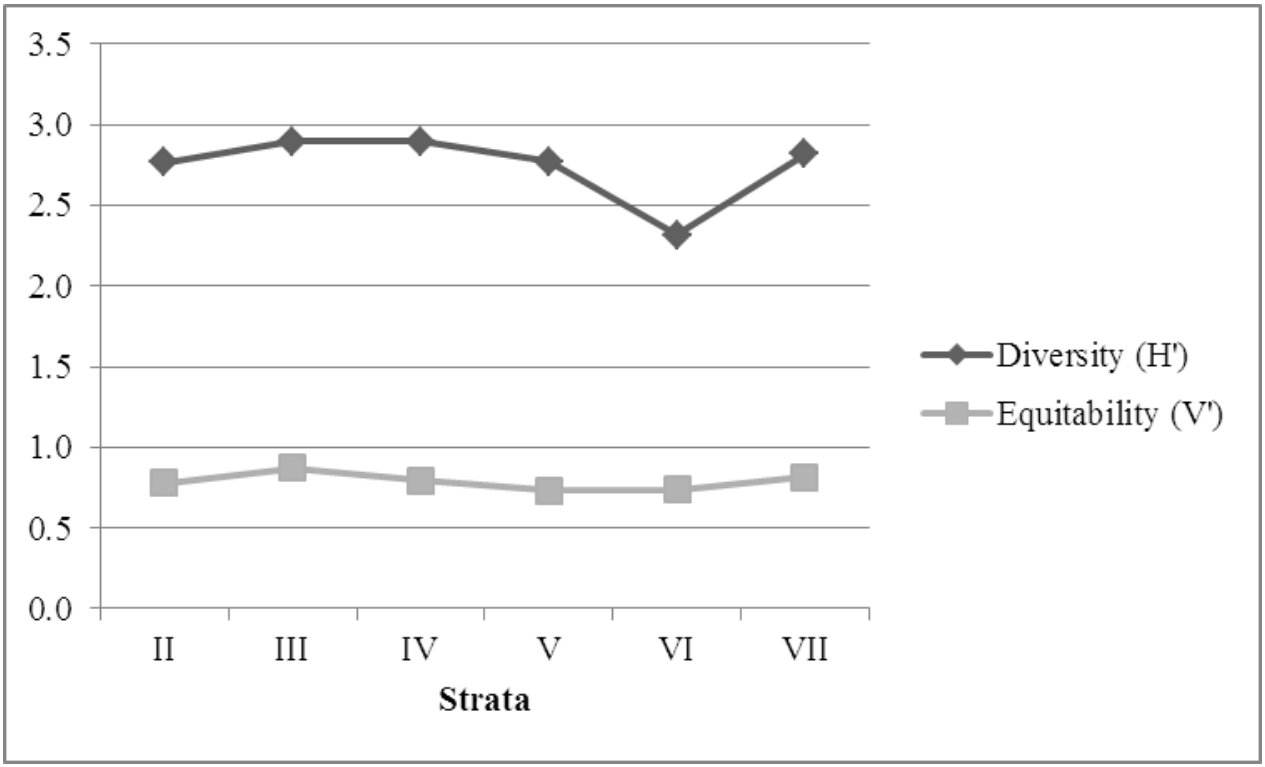

Figure 8. Heterogeneity measures for the small gastropod assemblage from CA-SMI-603. Changes in shellfish diversity and equitability through time are described by the Shannon-Weaver Diversity Function (H') and Equitability Function (V') (Reitz and Wing 2008).

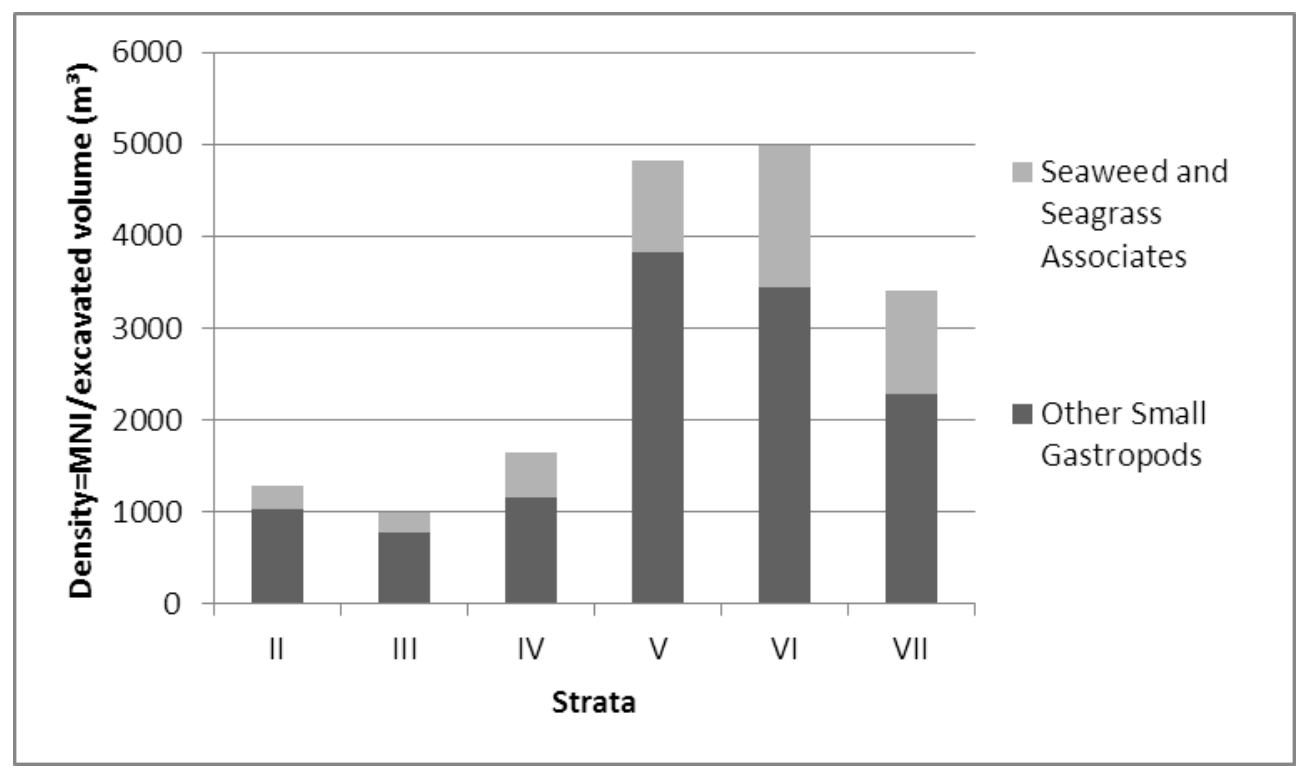

Figure 9. Density measures for small non-dietary gastropods from CA-SMI-603. 


\section{Relative Abundance of CA-SNI-40 Taxa}

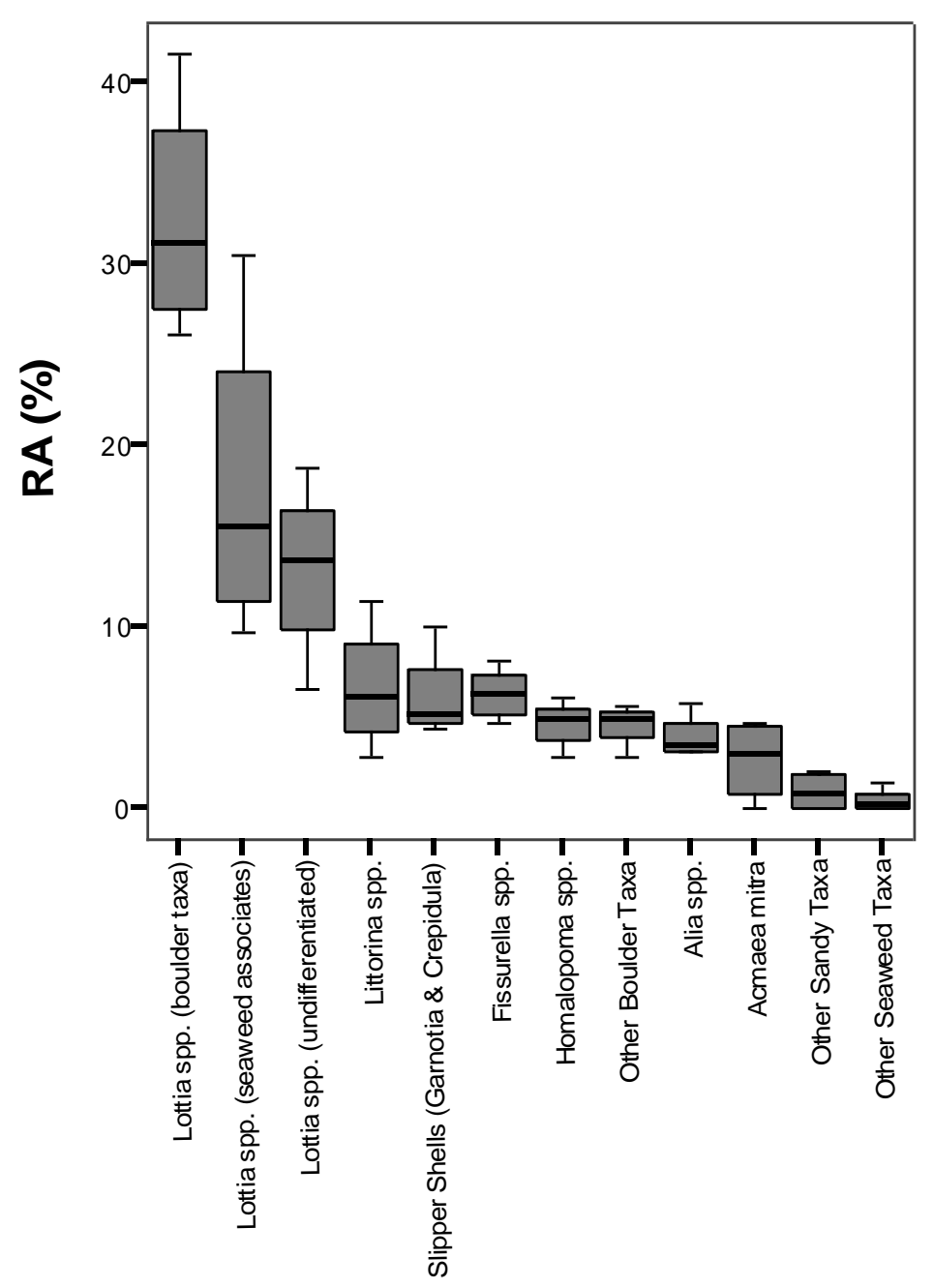

TAXA

Figure 10. Composition of small gastropod taxa from CA-SNI-40. Boxplots include mean relative abundance and interquartile ranges. Error bars denote full ranges. $N=$ number of analyzed deposits (4), $R A=$ relative abundance. 


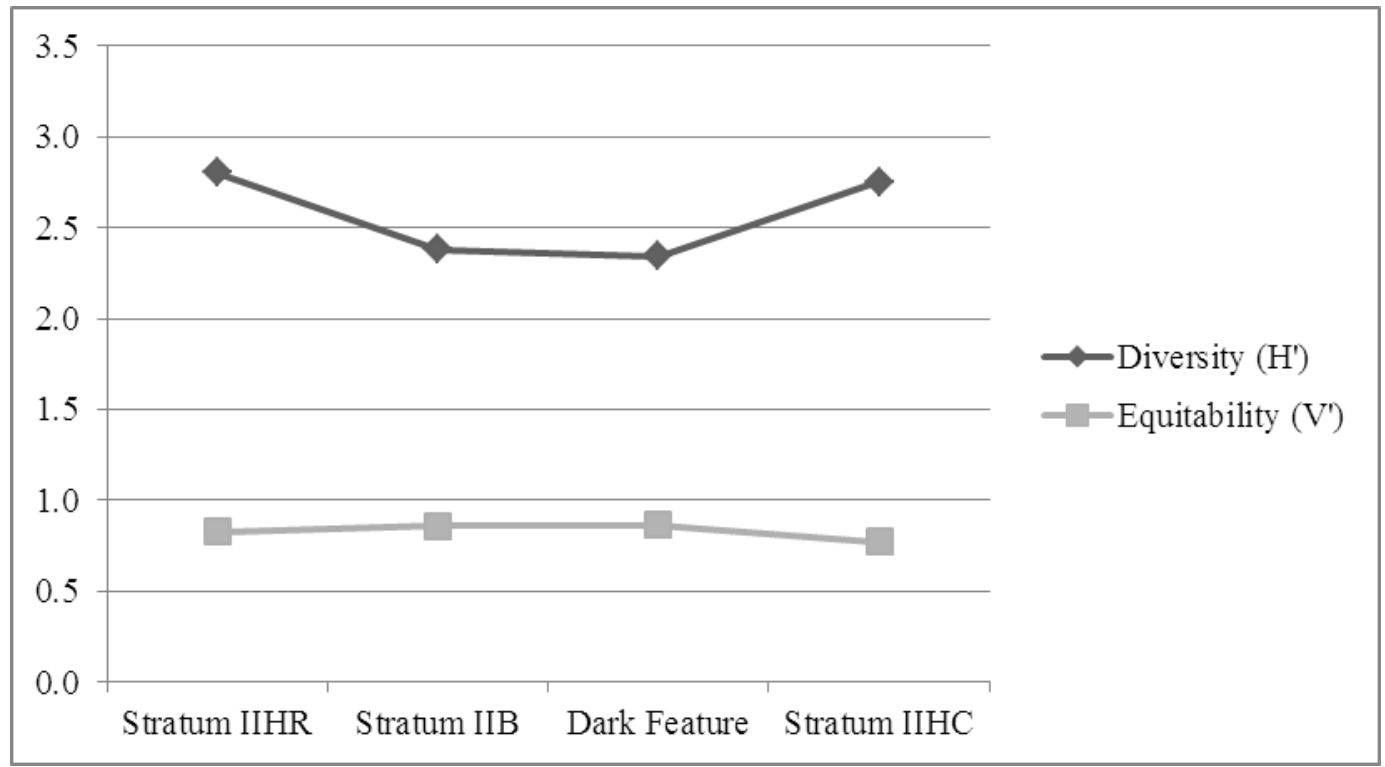

Figure 11. Heterogeneity measures for the small gastropod assemblage from CA-SNI-40. Changes in shellfish diversity and equitability through time are described by the Shannon-Weaver Diversity Function (H') and Equitability Function (V') (Reitz and Wing 2008).

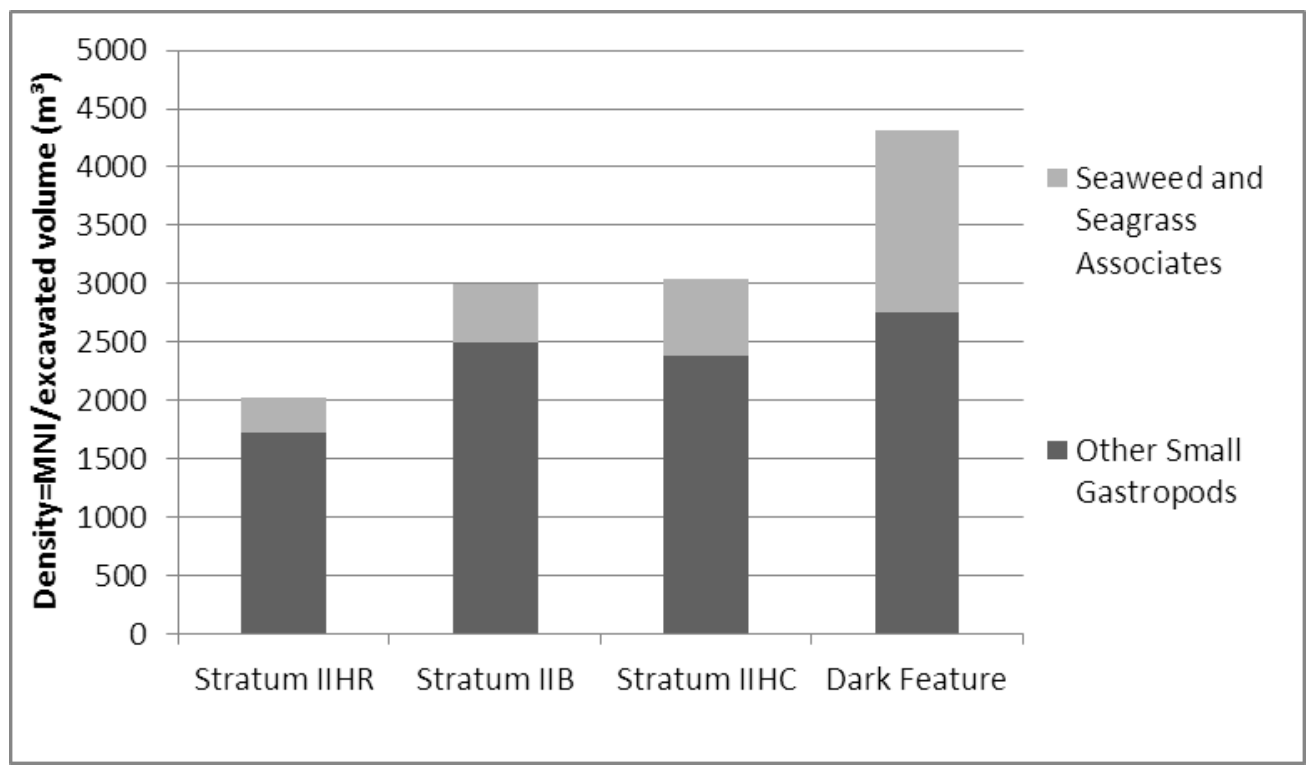

Figure 12. Density measures for small non-dietary gastropods from CA-SNI-40. 